\title{
Do anthropogenic, continental or coastal aerosol sources impact on a marine aerosol signature at Mace Head?
}

\author{
C. O'Dowd ${ }^{1}$, D. Ceburnis ${ }^{1}$, J. Ovadnevaite ${ }^{1}$, A. Vaishya ${ }^{1}$, M. Rinaldi ${ }^{2}$, and M. C. Facchini ${ }^{2}$ \\ ${ }^{1}$ School of Physics and Centre for Climate and Air Pollution Studies, Ryan Institute, National University of Ireland Galway, \\ University Road, Galway, Ireland \\ ${ }^{2}$ Istituto di Scienze dell'Atmosfera e del Clima, Consiglio Nazionale delle Ricerche, Bologna, Italy
}

Correspondence to: C. O’Dowd (colin.odowd@ nuigalway.ie)

Received: 10 February 2013 - Published in Atmos. Chem. Phys. Discuss.: 20 March 2013

Revised: 17 July 2014 - Accepted: 25 July 2014 - Published: 10 October 2014

\begin{abstract}
Atmospheric aerosols have been sampled and characterised at the Mace Head north-east (NE) Atlantic atmospheric research station since 1958, with many interesting phenomena being discovered. However, with the range of new discoveries and scientific advances, there has been a range of concomitant criticisms challenging the representativeness of aerosol sampled at the station compared to that of aerosol over the pristine open-ocean. Two recurring criticisms relate to the lack of representativeness due to potentially enhanced coastal sources, possibly leading to artificially high values of aerosol concentrations, and to the influence of long-range transport of anthropogenic or continental aerosol and its potential dominance over, or perturbation of, a natural marine aerosol signal. Here, we review the results of previous experimental studies on marine aerosols over the NE Atlantic and at Mace Head with the aim of evaluating their representativeness relative to that of a pristine openocean aerosol, i.e. with negligible anthropogenic/continental influence. Particular focus is given to submicron organic matter (OM) aerosol. In summary, no correlation was found between $\mathrm{OM}$ and black carbon (BC) in marine air conforming to clean-air sampling criteria, either at BC levels of $0-15$ or $15-50 \mathrm{ng} \mathrm{m}^{-3}$, suggesting that $\mathrm{OM}$ concentrations, up to observed peak values of $3.8 \mu \mathrm{g} \mathrm{m}^{-3}$, are predominantly natural in origin. Sophisticated carbon isotope analysis and aerosol mass spectral finger printing techniques corroborate the conclusion that there is a predominant natural source of $\mathrm{OM}$, with $80 \%$ biogenic source apportionment being observed for general clean-air conditions, rising to $\sim 98 \%$ during specific primary marine organic plumes when peak OM mass concentrations $>3 \mu \mathrm{g} \mathrm{m}^{-3}$ are observed. Similarly, a maximum con-
\end{abstract}

tribution of $20 \% \mathrm{OM}$ mass coming from non-marine sources was established by dual carbon isotope analysis. Further, analysis of a series of experiments conducted at Mace Head conclude that negligible coastal, surf zone, or tidal effects are discernible in the secondary or primary aerosol mass residing in the submicron size range for sampling heights of $7 \mathrm{~m}$ and above. The Mace Head marine-air criteria ensure anthropogenic and coastal effects are sufficiently minimised so as to guarantee a predominant, and sometimes overwhelming, natural marine aerosol contribution to the total aerosol population when the criteria are adhered to.

\section{Introduction}

The marine aerosol is perhaps the most important natural system globally in terms of climate effects. This is so because the ocean covers $70 \%$ of the earth's surface and marine aerosol haze and cloud layers are the most effective reflecting layers, given that they overlay a dark ocean surface (Charlson et al., 1987; Slingo, 1990). There are two generic marine aerosol types (O'Dowd and de Leeuw, 2007; de Leeuw et al., 2011): primary and secondary. Primary marine aerosol was initially considered to be predominantly sea salt, dynamically produced by wind stress interaction at the ocean surface; however, later it became evident that primary marine aerosol was better described as sea spray - a combination of sea salt and enriched primary organic matter (POM) resulting from biological processes at the ocean surface (O'Dowd et al., 2004; Facchini et al., 2008b). O'Dowd et al. (2004) identified WIOM 
(water-insoluble organic matter) with characteristics unique to surface ocean biological processes, while Facchini et al. (2008a) sampled only POM in the absence of secondary aerosol under controlled bubble-tank laboratory experiments using sea water sampled amidst a strong NE Atlantic bloom. One study by Keene et al. (2007), however, found high WSOM (water-soluble organic matter ) enrichment produced in a lab by bubble bursting using oligotrophic water and may be considered as contrasting, in particular, with the Facchini et al. (2008b) study. These two studies are not necessarily comparable: Keene et al. (2007) report high WSOM for low biologically active waters while Facchini et al. (2008a) report high WIOM for highly biologically active waters. The WIOM trend is consistent with an enriched POM source from biological processes; however, there is some suspicion concerning the experimental setup used to quantify the WSOM enrichment in Keene et al. (2007). For example, doubt has been raised regarding the representativeness of real ocean conditions using their sintered glass generator and excessively long bubble rise path which is thought to lead to artificially high enrichment in comparison to other techniques (Fuentes et al., 2010a; King et al., 2012); this would explain the high enrichment of WSOM, particularly in the absence of WIOM, in low biologically active water not seen in Atlantic waters. The secondary aerosol type (Facchini et al., 2008a) comprises a range of species produced in the gas phase or from gas phase processes and can be categorised as volatile organic compound (VOC) oxidation products in the condensed phase (Rinaldi et al., 2011) or non-sea-salt (nss) sulfate produced from the oxidation of dimethyl sulfide (DMS); a hybrid organo-sulfur species such as methanesulfonic acid (MSA), also a DMS oxidation product, can also be present in significant quantities. Organo-nitrogen, in the form of dimethyl amine (DMA) is also present to a lesser degree (Facchini et al., 2008a). More often than not, secondary inorganic aerosol such as nss sulfate dominates over secondary organic aerosol (SOA) as reported in Dall'Osto et al. (2010); however, this study related to a brief snapshot relatively early in the season (late May-early June) when considering that peak productivity and peak OM enrichment occurs in $\mathrm{Au}-$ gust (noting that in Dall'Osto et al., only concentration and not enrichment was reported).

In pristine environments (e.g. Antarctica, with negligible anthropogenic/continental influence), it can be quite a challenge to characterise the marine aerosol since the primary aerosol depends on dynamics producing the spray, on biological activity which determines the organic matter enrichment, and on oxidant availability which can chemically transform/age POM to SOA-like OM (organic matter) in the spray itself - all processes which are highly variable in time and space (Rinaldi et al., 2010; Decesari et al., 2011). Similarly, biological activity, sea water temperature, sea-to-air transfer, wave dynamics, cloudiness, photolysis rates, etc., all influence the concentration of marine SOA. The problem is further compounded by the fact that basic organic, sulfate, and nitrate analytical techniques cannot source apportion these chemical species and, thus, cannot conclusively elucidate whether or not they are natural or anthropogenic in origin.

The challenge is to understand as many of the key marine aerosol processes driving formation, transformation, and climate impacts, but how is this to be achieved? Intermittent and ad hoc cruises are used to access so-called remote and pristine regions; however, their spatial and temporal snapshots are limited and only provide glimpses of the complete picture, often missing high-wind-speed events or regions of high biological productivity. Aircraft missions, while excellent for providing vertical structure information, have even greater limitations, particularly in the context of long temporal data sets. Coastal stations provide a solution to the temporal sampling problem, although these are limited to a fixed spatial location but the question arises as to whether or not there are local sources contaminating the "open-ocean marine" signal and/or how pristine the apparent open-ocean marine aerosol is.

The problem is that, wherever sampling of marine aerosol is conducted, particularly if the focus is on the submicron fraction, there exist significant challenges relating to contamination whether it be anthropogenic or related to coastal topographical issues. If such contamination exists, do we "throw the baby out with the bath water" or is there an acceptable level of contamination which will still allow the elucidation and quantification of natural aerosol processes? This is, of course, a subjective question; we know that there is longrange pollution transport to Antarctica, as seen in the black carbon records. Does this mean that Antarctica is not a useful location to study natural aerosol? Clearly, the answer is no, it depends on whether or not the natural signal is overwhelmed by the contaminated signal. What is an acceptable contamination threshold: $1,5,10,25 \%$ ? If we contrast the NE Atlantic marine aerosol entering into Europe in the Mace Head region, black carbon mass is higher than that in Antarctica, although it is also perhaps one of the most biologically rich and stormiest oceans there is. Again, is there a sufficient natural open-ocean signal to elucidate key processes or should such experiments be abandoned? This study reviews some of the key experiments conducted at Mace Head and evaluates how they have been interpreted, or, in some cases, misinterpreted, with the aim of elucidating the conditions acceptable for non-contaminated marine aerosol research.

\section{The Mace Head facility}

The Mace Head Atmospheric Research Station is located in Connemara, County Galway, on the Atlantic Ocean coastline of Ireland at $53^{\circ} 19^{\prime} \mathrm{N}, 9^{\circ} 53^{\prime} \mathrm{W}$ and offers a marine sector from $190^{\circ} \mathrm{W}$ through to $290^{\circ} \mathrm{W}$ (see Fig. 1). Meteorological records show that on average, over $60 \%$ of the air masses arrive at the station in the marine sector (Jennings et al., 2003; O'Connor et al., 2008). Air is sampled 

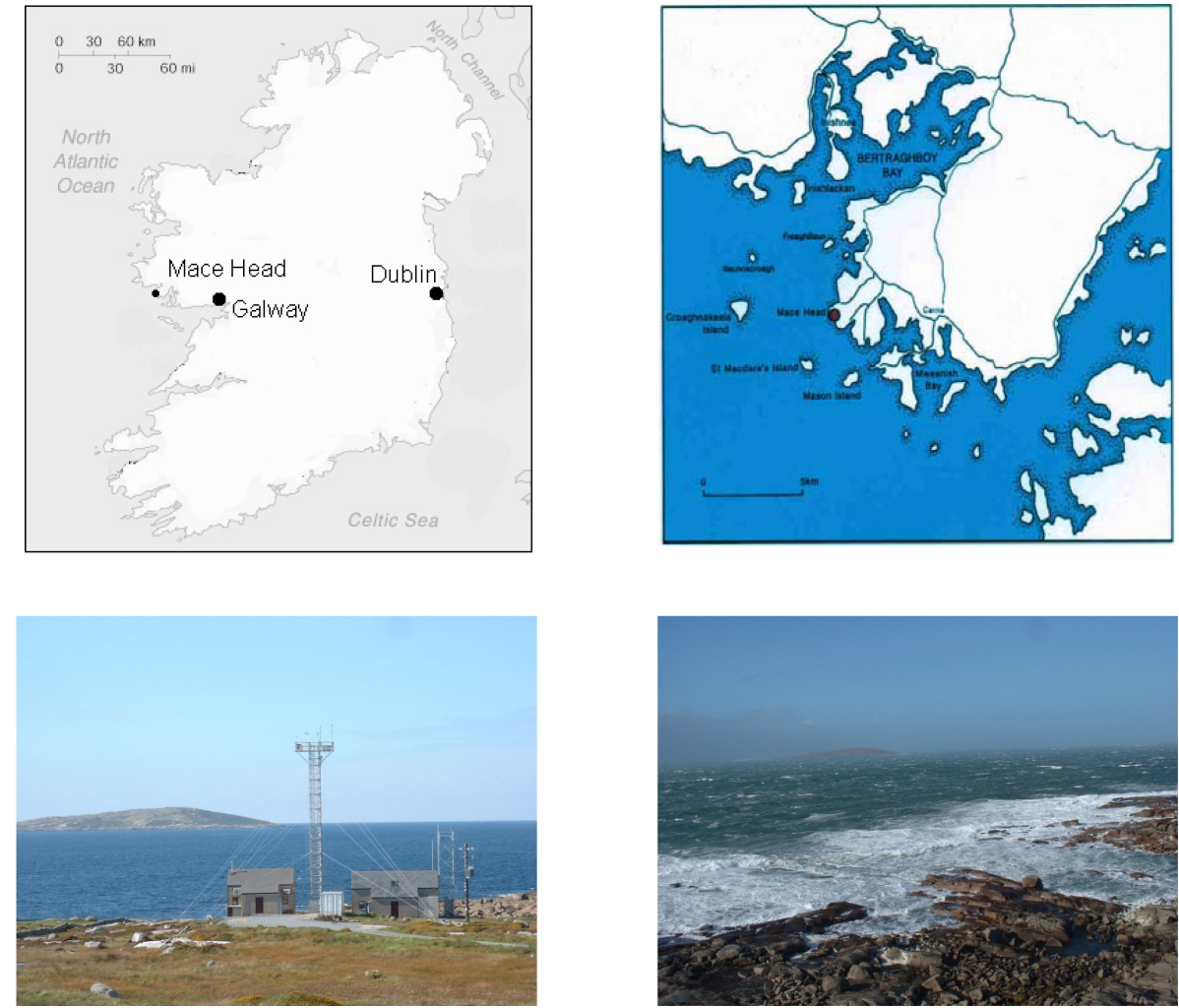

Figure 1. Top: map of Ireland illustrating the location of Mace Head and local area map; bottom: Mace Head shore labs and $22 \mathrm{~m}$ tower and shore topography at Mace Head.

from a $10 \mathrm{~m}$ high tower and a $22 \mathrm{~m}$ tower, both situated $\sim 100 \mathrm{~m}$ from the shoreline and $\sim 50 \mathrm{~m}$ from high water (http://www.macehead.org.). The shoreline is relatively inhomogeneous and rocky with a slope of $\sim 4^{\circ}$. The $22 \mathrm{~m}$ tower is situated between two $8 \mathrm{~m}$ high "shore" laboratories (Fig. 1) while the $10 \mathrm{~m}$ tower is located adjacent to the north gable of the more northerly aerosol laboratory. The southerly shore laboratory hosts the gas sampling experiments. Also shown in Fig. 1 is the whitecap and surf zone field under moderately windy conditions. Table 1 summarises the various sampling details of the relevant research papers reporting data at Mace Head.

\section{Interpretation of previous results}

\subsection{Aerosol characterisation under wind-sector controlled sampling}

In the absence of highly sophisticated and expensive analytical techniques capable of directly apportioning a particular aerosol chemical species to a particular source, there are a number of real-time and post-analysis procedures used to try to distinguish between pristine, or baseline, marine aerosol and that which is significantly influenced by anthropogenic sources. These filtering approaches range from wind-sector controlled sampling in real time, sometimes augmented by parallel total particle concentration control, to post analysis of air mass back trajectories, BC (black carbon) mass concentrations, and/or correlations between the concentration of the species being measured and an anthropogenic tracer such as $\mathrm{BC}$ or $\mathrm{CO}$; these are discussed in the following sections.

Some of the first chemical mass measurements undertaken at Mace Head were from August 1989 to August 1990 by Savoie et al. (2002). The $22 \mathrm{~m}$ tower was used for the aerosol filter sampling. The aerosol sampler was connected to a clean-sector controller which was designed to capture clean marine onshore winds; however, nss-sulfate mass concentrations of up to $10-20 \mu \mathrm{g} \mathrm{m}^{-3}$ were reported, along with nitrate mass concentrations exceeding $10 \mu \mathrm{g} \mathrm{m}^{-3}$. Clearly, these concentrations cannot be regarded as representative of clean marine air advecting in off the Atlantic. Can these results be interpreted, as concluded by Savoie et al. (2002), as the Mace Head marine sector aerosol composition being significantly impacted by anthropogenic emissions and as, on average, $85-90 \%$ of the nss sulfate in marine flow at Mace Head originating from anthropogenic sources? On face value, this could indeed be the conclusion one arrives at; however, closer examination of the experimental and sampling criteria reveals a different conclusion. 
Table 1. Summary of the sampling details from the relevant research papers reporting data at Mace Head.

\begin{tabular}{|c|c|c|}
\hline Research paper & Sampling details & Observation period \\
\hline Savoie et al. (2002) & $\begin{array}{l}\text { Onshore winds (undefined sector), } 22 \mathrm{~m} \\
\text { tower }\end{array}$ & $1989-1990$ \\
\hline McArdle et al. (1998) & Non-sectored & 1993-1994 \\
\hline O’Dowd et al. (2004) & Sector $\quad 190-300^{\circ}, \quad \mathrm{CN}<900 \# \mathrm{cc}^{-1}$, & 2002 \\
\hline Cavalli et al. (2004) & $\mathrm{EBC}<70 \mathrm{ng} \mathrm{m}^{-3}, 3 \mathrm{~m}$ height & Only six samples collected \\
\hline Geever et al. (2005) & $22 \mathrm{~m}$ tower & May-June 2002 \\
\hline Coe et al. (2006) & 7 and $22 \mathrm{~m}$, alternating & July-August 2002 \\
\hline Yoon et al. (2007) & Sector $190-300^{\circ}, \mathrm{CN}<700 \# \mathrm{cc}^{-1}$, & 2002-2004 \\
\hline Facchini et al. $(2008 \mathrm{a}, \mathrm{b})$ & $\mathrm{EBC}<50 \mathrm{ng} \mathrm{m}^{-3}, 10 \mathrm{~m}$ height & 2006 \\
\hline Rinaldi et al. $(2009,2011)$ & $\mathrm{RV}$ Celtic Explorer $14 \mathrm{~m}$ deck & 2006 and 2006-2009 \\
\hline Ceburnis et al. (2011) & & 2006 \\
\hline Ceburnis et al. (2008) & $\begin{array}{l}3,10,30 \mathrm{~m} \text { height parallel sampling, } \\
\text { sector } \quad 190-300^{\circ}, \quad \mathrm{CN}<700 \# \mathrm{cc}^{-1} \text {, } \\
\text { EBC }<50 \mathrm{ng} \mathrm{m}^{-3} \text {. }\end{array}$ & 2005 \\
\hline Dall'Osto et al. (2010) & $10 \mathrm{~m}$ height community sampling duct & 2008 \\
\hline Ovadnevaite et al. (2011a, b, 2012) & (applies to $\mathrm{CN}$ above) & 2009-2010 \\
\hline
\end{tabular}

While the aforementioned experimental studies were pioneering and revealing, the experimental design of the sampling component of the study was not completely fit for purpose in that the criterion used to exclude polluted European air masses, which can recirculate into the marine sector, was insufficient. In contrast, subsequent studies by O'Dowd et al. (2004), Cavalli et al. (2004), Yoon et al. (2007), and Ceburnis et al. (2011) used a more sophisticated set of sampling criteria: from 2001, the Mace Head active sector-controlled sampling system used not only wind direction but also total particle concentration, or condensation nuclei $(\mathrm{CN})$, as the primary controllers for sampling onshore clean marine air masses. Total particle concentration was measured by a TSI $7610 \mathrm{CN}$ particle counter $\left(D_{50}>14 \mathrm{~nm}\right)$, and the counter was set to trigger sampling shutdown if particle counts exceeded 700 particles $\mathrm{cm}^{-3}$ (from 2006 onwards, the TSI 7610 model was replaced by the TSI 3010 condensation particle counter $\left(D_{50}>10 \mathrm{~nm}\right)$, effectively reducing the particle number threshold). The sampling shutdown time was set to $30 \mathrm{~s}$, followed by a re-start time of $5 \mathrm{~min}$, resulting in the possibility that the sample could be polluted $10 \%$ of the time; however, this possible pollution sampling time corresponds to the an extreme scenario of the sample switching on and off every $5 \mathrm{~min}$ for the duration of the week's sampling, which, of course, does not happen in practice. Conditions suitable for sampling are normally sustained for many hours at a time, and even if they could only be sustained for an hour at a time, this leads to a $1 \%$ contamination time frame. The real-time clean-air control criteria were evaluated in a post analysis quality control check during which additional criteria were deployed, namely, air mass back trajectories free from land contact for $96 \mathrm{~h}$ prior to arrival at Mace Head and EBC (equivalent BC) concentration measured by an Aethalometer (AE-16, Magee Scientific, single wavelength at $880 \mathrm{~nm}$ ) not exceeding $50 \mathrm{ng} \mathrm{m}^{-3}$ as an upper limit. The air mass back trajectories are only used as supporting evidence to show that air of marine origin has spent the last $48 \mathrm{~h}$ in the marine boundary layer, as presented by, e.g., Cavalli et al. (2004) and Ceburnis et al. (2011), facilitating wet deposition of pre-existing aerosol particles (e.g. of North American origin) and replenishment with nascent seaspray aerosol particles. The EBC value of $50 \mathrm{ng} \mathrm{m}^{-3}$ is the limit value and should not be confused with the actual values. In practise the actual values in sectored marine air masses are typically $10-20 \mathrm{ng} \mathrm{m}^{-3}$ (Cooke et al., 1997; Junker et al., 2006). The mass attenuation coefficient of Aethalometer AE-16 was $16.8 \mathrm{~m}^{2} \mathrm{~g}^{-1}$. Junker et al. (2006) indicated that thermo-optical method suggested a much higher value $\left(35 \mathrm{~m}^{2} \mathrm{~g}^{-1}\right)$ in clean marine sector samples, which would result in an even lower threshold BC value of $24 \mathrm{ng} \mathrm{m}^{-3}$ and the typical clean marine sector values of only $5-10 \mathrm{ng} \mathrm{m}^{-3}$, which would then be comparable to $\mathrm{BC}$ values from the pristine environments (Hansen et al., 1988; Hara et al., 2008; Sciare et al., 2009; Shank et al., 2012). In summary it suggests that EBC values reported for MH (Mace Head) are most likely systematically biased high. The choice of $\mathrm{CN}$ or particle number concentration and $\mathrm{BC}$ mass concentration thresholds is somewhat arbitrary; however, the choice of $700 \mathrm{CN} \mathrm{m}^{-3}$ is consistent with studies in the remote Southern Hemisphere; for example, O’Dowd et al. (1997) found 
that total $\mathrm{CN}$ in pristine air below $53^{\circ} \mathrm{S}$ over the South Atlantic and Weddell Sea, Antarctica, while generally less than $500 \mathrm{~cm}^{-3}$, often reached $700 \mathrm{~cm}^{-3}$ in clean air outside new particle production events. Further, Dall'Osto et al. (2010) found that the marine sector $\mathrm{CN}$ frequency distribution was bimodal, with a background mode concentration of 400$600 \mathrm{~cm}^{-3}$. For EBC, O'Dowd et al. (1993) found that NE Atlantic background marine air masses comprised EBC mass concentrations between 10 and $35 \mathrm{ng} \mathrm{m}^{-3}$ while the lowest EBC mass concentration in modified marine air was observed to be $220 \mathrm{ng} \mathrm{m}^{-3}$. Cooke et al. (1997) provided statistical evidence that marine air masses with $\mathrm{CN}$ concentrations lower than $700 \mathrm{~cm}^{-3}$ were associated with EBC concentrations lower than $75 \mathrm{ng} \mathrm{m}^{-3}$. Based on these studies, it seemed reasonable to select the stricter threshold of $50 \mathrm{ng} \mathrm{m}^{-3}$. The threshold seems to be justified when the correlation between $\mathrm{CN}$ number and EBC mass concentration is analysed. The minimum averaging time of an aethalometer, and thus resolution, was $5 \mathrm{~min}$ and was further averaged for $1 \mathrm{~h}$ which was significantly less noisy than 5 min data: standard deviations for $1 \mathrm{~h}$ and $5 \mathrm{~min}$ data were $5 \mathrm{ng} \mathrm{m}^{-3}$ and $20 \mathrm{ng} \mathrm{m}^{-3}$, respectively. For a typical OM plume event, shown in Fig. 2, lasting about 1 day, EBC mass concentration ranged from 4 to $27 \mathrm{ng} \mathrm{m}^{-3}$, while $\mathrm{CN}$ remained less than $700 \mathrm{~cm}^{-3}$ with no correlation being evident $\left(R^{2}=0.05\right)$. Extending the averaging timescale from 5 to 60 min reduced the standard deviation from 20 to $5 \mathrm{ng} \mathrm{m}^{-3}$, thus demonstrating that almost all data reported are indeed above the noise level. For an extended period from 1 January to 31 May 2009, comprising of $995 \mathrm{~h}$ of data that meet the criteria of CN less than $700 \mathrm{~cm}^{-3}$, wind direction of $190-300^{\circ}$, and non-recirculating marinesector air mass back trajectories, no correlation is observed either $\left(R^{2}=0.06\right)$. Regarding the extended case, $1.6 \%$ of the data records reside outside the $50 \mathrm{ng} \mathrm{m}^{-3}$ threshold; however, the contaminated samples amount to a negligible percentage of data in this category; in any event, they are removed because they exceed the $50 \mathrm{ng} \mathrm{m}^{-3}$ threshold. The lack of correlation between $\mathrm{CN}$ and $\mathrm{EBC}$ below the $50 \mathrm{ng} \mathrm{m}^{-3}$ threshold suggests a credible set of criteria for marine background air mass sampling. The absence of correlation between $\mathrm{CN}$ and EBC may be partially attributed to different sources as nucleation events contribute to $\mathrm{CN}$ but not EBC. However, any nucleation events would typically exceed the threshold of $700 \mathrm{~cm}^{-3}$ by at least 3 times or more and thus be excluded from the regression. Consequently, some of the clean air can, indeed, be excluded, but the conservative approach is useful in avoiding significant contamination of samples by anthropogenic air masses (noting that in polluted air masses, a correlation between $\mathrm{CN}$ and EBC would be expected as the peak in both their number (for $\mathrm{CN}$ ) and mass (for $\mathrm{EBC}$ ) size distribution occurs over the same size range $(30-70 \mathrm{~nm})$ ). In any event, exclusion of some clean air certainly does not compromise the integrity of the data and, more importantly, the clean-air data are examined by numerous state-of-the-art methods discussed below, thereby corroborating the robustness of the clean-sector sampling system.

As it happened, in 2004, both the Savoie-type and the NUIG (National University of Ireland, Galway)-type marine sector controllers were run in parallel and a scatter plot of their relationship is illustrated in Fig. 3 where each point represents nss-sulfate mass over a week-long sample (noting that the actual sampling time depends both on the air mass and on the sampling criteria used). Although the Savoie system sampled total suspended particulate (TSP) matter and the NUIG system used a Berner impactor with an upper size cut of $16 \mu \mathrm{m}$ diameter, the systems effectively cover the same size range. The comparison indicates that the Savoie-type sector controller, more often than not, reports higher nss-sulfate masses compared to the NUIG system, often by a factor of 2 or 3. Also shown in Fig. 3 are two contrasting cases from the 2004 data set, visualised by air mass back trajectories: one in which only the Savoie-type controller sampled and, in fact, sampled only recirculating polluted air, as the particle concentration was above the clean-air threshold in the NUIG controller for the whole duration of the week; and one in which both systems successfully sampled clean air coherently throughout the week (i.e. due to the lack of circulating air in this case). In summary, Fig. 3 presents compelling evidence that the new sector system is far superior to the system used by Savoie et al. (2002) in ensuring the sampled air is cleaner than ever before. However, the results of this comparison should be considered together with other lines of evidence (carbon isotopes, HR-ToF-AMS (high-resolution time-of-flight aerosol mass spectrometry), HNMR (nuclear magnetic resonance)), all of which are discussed later.

The measurements taken by Savoie et al. (2002) were conducted 25 years ago, and while pioneering, it can only be concluded that the experimental design was not completely fit for purpose. Consequently, the results from that experiment simply cannot be used to refute more recent experiments in terms of source apportionment. Apart from the experimental design, there are two additional reasons as to why great caution should be exercised when comparing more recent studies with the 25-year old Savoie et al. (2002) study. First, the measurements of nss sulfate by Savoie et al. (2002) related to bulk mass measurements where the nss-sulfate mass is derived from $\mathrm{Na}$ and sea-salt sulfate concentrations, both very large numbers, relatively speaking, which result in large errors associated with the derivation of the much smaller nss-sulfate mass. This analytical uncertainty is particularly severe for bulk filter analysis compared to sizesegregated impactor sample analysis. Second, the emissions of anthropogenic $\mathrm{SO}_{2}$ have reduced over the recent 2 decades and the annual average reduction in nss-sulfate mass at Mace Head has reduced by $70 \%$ over the last 10 years (O'Dowd et al., 2013). While sulfate mass trends are not available at Mace Head for the 1990s, $\mathrm{SO}_{2}$ trends from the nearby Valentia GAW (Global Atmospheric Watch) station (http://www. emep.int) reveal an even greater reduction for the previous 

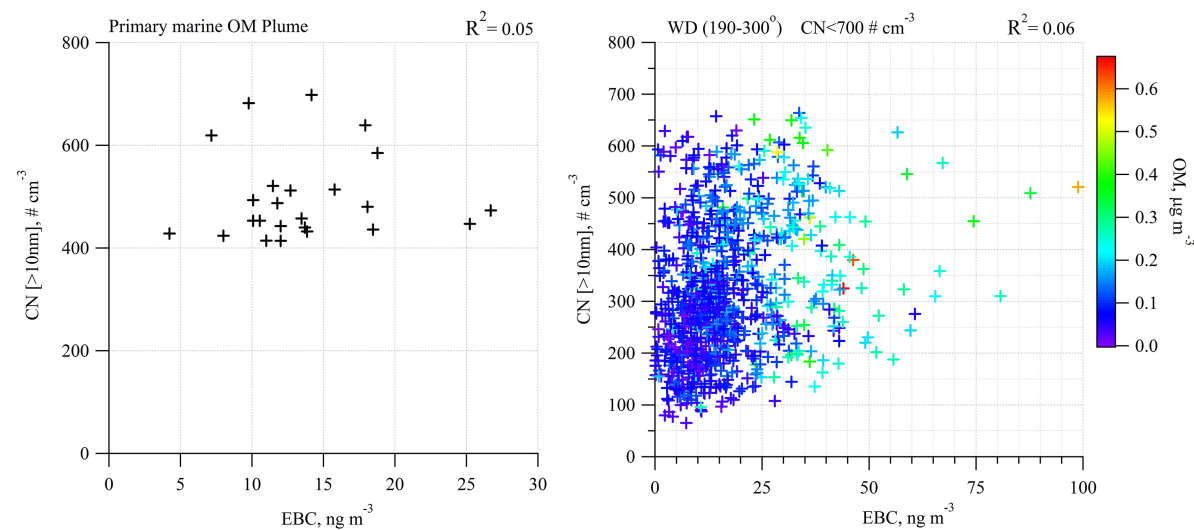

Figure 2. Left: scatter plot of CN vs. EBC for an organic sea-spray event lasting approximately 30 h. Right: scatter plot of CN vs. EBC for

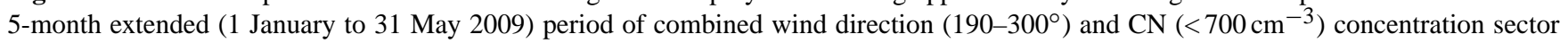
control.

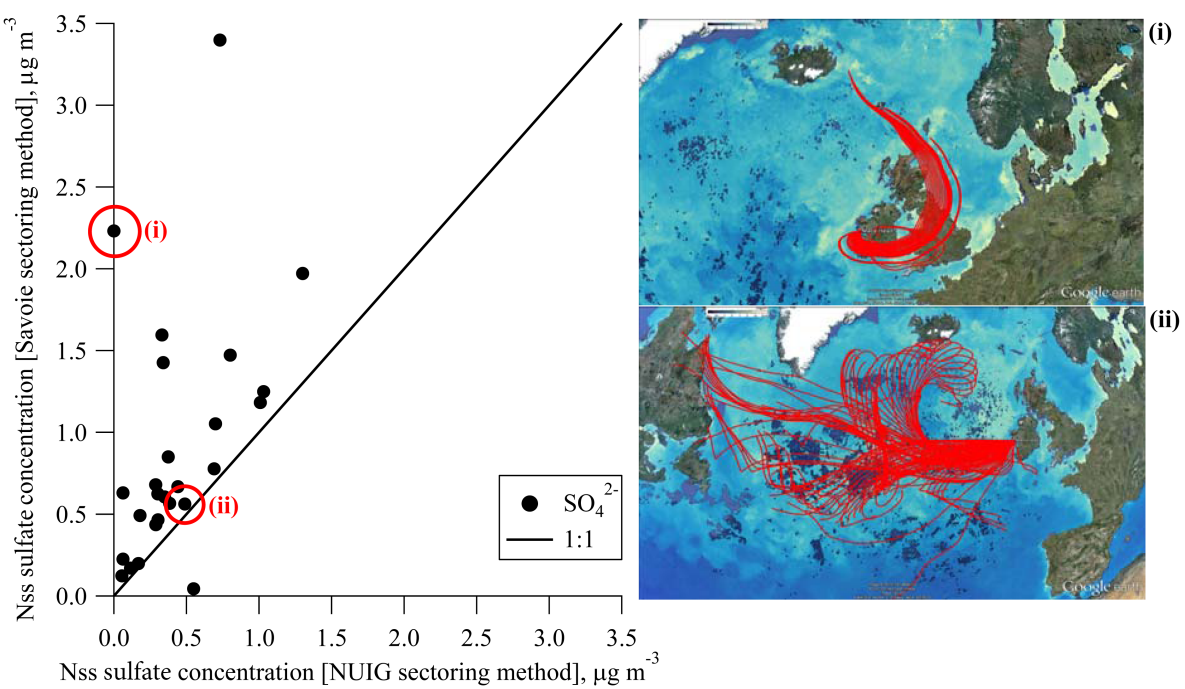

Figure 3. Scatter plot (left) of total nss-sulfate mass concentrations during 2004 at Mace Head obtained by using only the offshore wind sectoring system (according to Savoie et al., 2002) and the clean marine sectoring system used by NUIG (e.g. Cavalli et al., 2004; Yoon et al., 2007; Ceburnis et al., 2011). Each point corresponds to a 1-week sample; however, the total number of hours of actual sampling time depends on the clean-sector sampling criteria. On the right, the $96 \mathrm{~h}$ air mass back trajectories at $500 \mathrm{~m}$ presented in Google Earth ${ }^{\circledR}$ represent two contrasting cases often encountered: (i) 1 week in which the Savoie-type sector controller sampled polluted recirculation air based on wind direction, while the NUIG system sampled nothing due to the total particle concentration exceeding the nominal threshold concentration of $700 \mathrm{~cm}^{-3}$ (resulting in the largest difference seen in the scatter plot); and (ii) a week-long case in which both systems ran coherently as all marine sector trajectories were truly marine (resulting in almost $1: 1$ agreement on the scatter plot).

decade, suggesting that sulfate mass is likely to have reduced by $\sim 80 \%$ over the last 25 years. The significant reduction in anthropogenic sulfur emissions is likely to explain the better agreement between the NUIG and Savoie-type 2004 data compared to the 1989-1990 Savoie et al. (2002) data. In summary, an experimental set-up not completely appropriate for the task, high uncertainties associated with the analytical techniques, and the estimated $\sim 80 \%$ reduction in anthropogenic sulfate mass since the Savoie et al. (2002) study means that it is simply not justified to claim, these days, that marine air masses arriving at Mace Head are 85-90\% influenced by anthropogenic aerosols.

\subsection{Organic-mass-black-carbon relationships and ratios}

In our discussion, we focus mainly on the magnitudes of $\mathrm{OM}$ and the $\mathrm{OM} / \mathrm{EBC}$ ratio to determine the origin of the OM since nss sulfate can have both a natural marine and anthropogenic origin; these results are compared to those of Shank et al. (2012). It should be noted, however, that 

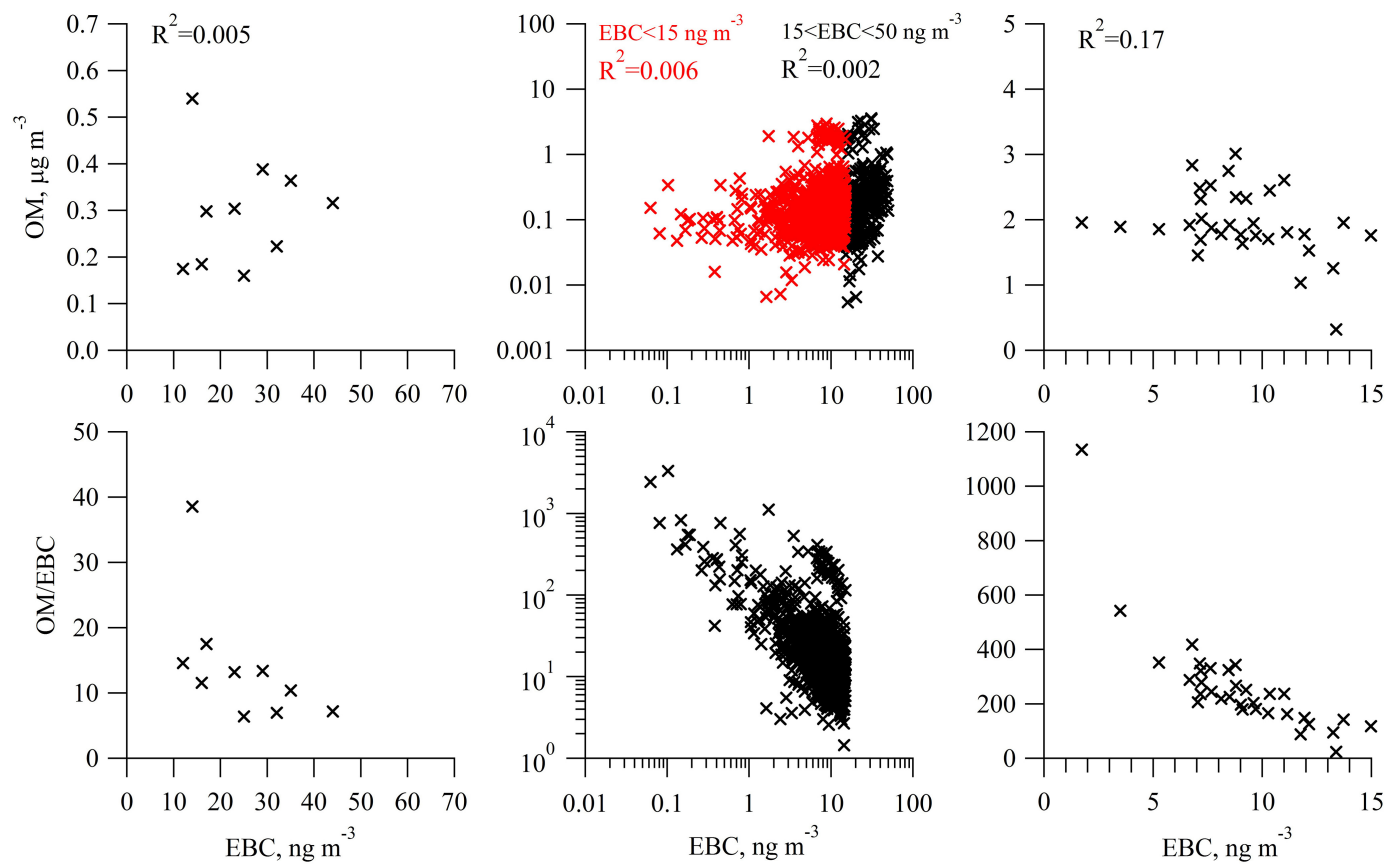

Figure 4. Top left: $\mathrm{PM}_{1} \mathrm{OM}$ vs. EBC for off-line sampling (per point, $\sim 70 \mathrm{~h}$ of accumulated marine sector sampling over 1-week period per point) from Yoon et al. (2007). Bottom left: Yoon et al. (2007) OM/EBC ratios vs. EBC. Top middle: OM vs. EBC for 3 years of online AMS

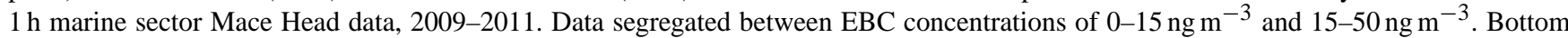
middle: 3 years $\mathrm{OM} / \mathrm{EBC}$ ratios for $\mathrm{EBC}<15 \mathrm{ng} \mathrm{m}^{-3}$. Top right: $\mathrm{OM}$ vs. EBC from AMS $1 \mathrm{~h}$ average data during primary marine organic plumes (Ovadnevaite et al., 2011b). Bottom right: OM/EBC ratios vs. EBC during primary marine organic plumes.

Shank et al. (2012) present their AMS measurements of OM as being effectively the total OM aerosol mass, based on an incorrect interpretation of O'Dowd et al. (2004) in that Shank et al. (2012) cite this study as having demonstrated that more than $90 \%$ of the mass is within submicron sizes (i.e. the size range covered by their AMS). The correct interpretation of O'Dowd et al. (2004) is that, while the percentage mass contribution of OM is up to $5 \%$ in supermicron sizes, approximately $50 \%$ of the total OM resides in the supermicron sizes. Consequently, the Shank et al. (2012) OM data refer mostly to only the submicron component.

During the Shank et al. (2012) TAO (Tropical Atmosphere Ocean) cruise (Pacific Ocean $125-145^{\circ} \mathrm{W}$ and $8^{\circ} \mathrm{N}-8^{\circ} \mathrm{S}$ ), an OM mass concentration ranging from 0.07 to $0.17 \mu \mathrm{g} \mathrm{m}^{-3}$ was found for screened clean marine air, and a VOCALS (VAMOS Ocean-Cloud-Land Study, in the south-east Pacific region of $15-30^{\circ} \mathrm{S}$ ) average of $0.07 \mu \mathrm{g} \mathrm{m}^{-3}$ was encountered over Pacific waters. Clean-air conditions were defined as $\mathrm{BC}<4.5 \mathrm{ng} \mathrm{m}^{-3}$ and $\mathrm{CO}<61 \mathrm{ppb}$. This is compared (Fig. 4) to Mace Head off-line Berner-derived OM mass, ranging from 0.16 to $0.54 \mu \mathrm{g} \mathrm{m}^{-3}$ and $0.05-3 \mu \mathrm{g} \mathrm{m}^{-3}$ for 3 years of Mace Head on-line AMS data, increasing to $>3 \mu \mathrm{g} \mathrm{m}^{-3}$ in specific primary organic sea-spray plumes. Shank et al. (2012) concluded that OM was correlated to BC down to concentrations as low as $2 \mathrm{ng} \mathrm{m}^{-3}$ and that most of the average OM observed in their Pacific studies was anthro- pogenic. Further, they also note that it may not be appropriate to fix a threshold OM mass concentration below which the OM can be considered as non-perturbed marine air and suggest that a large fraction of OM mass observed at Mace Head is therefore anthropogenic. There is no justification to conclude that, because high OM is observed over a different ocean, the OM is non-marine. Figure 4 shows the scatter plots of OM vs. EBC for BC mass concentration less that $15 \mathrm{ng} \mathrm{m}^{-3}$ for NE Atlantic aerosol sampled at Mace Head. What is observed is, more or less, no correlation between the two variables, even for extraordinary high OM concentrations of $>3 \mu \mathrm{g} \mathrm{m}^{-3}$, suggesting that the OM reported as marine $\mathrm{OM}$ at Mace Head is indeed dominated by clean marine $\mathrm{OM}$ aerosol.

Shank et al. (2012) also analysed the OM / BC ratio; they found a ratio of 10 in the remote Pacific and argued that even this approach was not robust, given the large range of ratios encountered both in remote and clean marine environments as well as in polluted air. We expand the collection of $\mathrm{OM} / \mathrm{EBC}$ ratios (Table 2) to include additional southern hemisphere oceanic ratios along with our average Mace Head ratios. We find an OM/EBC ratio of 60 for Amsterdam Island, 28 for Mace Head non-organic-plume events, and 182 for primary organic sea-spray plumes detected at Mace Head. In fact, for hour-average data, ratios approaching 1000 are seen. Such high OM/EBC ratios over EBC mass 
concentrations from 0 to $15 \mathrm{ng} \mathrm{m}^{-3}$ provide compelling arguments supporting the case that $\mathrm{OM}$ observed under the clean-air criteria at Mace Head is indeed dominated by natural marine OM.

In summary, it appears that the $\mathrm{OM} / \mathrm{EBC}$ ratio is a rather ambiguous parameter to infer the origin of $\mathrm{OM}$, especially when multiple air masses are mixed in the same sample, with the possible exception of when the ratio is extremely low (e.g. 2-5).

\subsection{Chemical source apportionment}

The first attempt to source apportion the secondary aerosol measured at Mace Head centred on sulfur isotope analysis conducted from 1993 to 1994 by McArdle et al. (1998). The study revealed a maximum biogenic sulfur contribution to total sulfur mass of $30 \%$ in spring and summer and significantly less throughout the remainder of the year. In this study, samples were taken in all wind sectors. Results from this experiment could not elucidate the anthropogenic contamination contributing to the baseline marine signal since the analysis included all marine and continental air masses. A more recent attempt to source apportion sulfate aerosol over the Atlantic was undertaken by Lin et al. (2012), when they conducted east-west and north-south transects of the Atlantic. Of particular relevance to the discussion in this study is the east-west transect along $36^{\circ} \mathrm{N}$, departing from midway along the USA east coast and arriving in Europe in the south of Portugal. The isotopic source apportionment of nss sulfate demonstrates that, close to the US east coast (e.g. sample 4 in Fig. 5, corresponding to $-68.9^{\circ} \mathrm{E}, 36.22^{\circ} \mathrm{N}$ ), nss sulfate is $70-80 \%$ anthropogenic in origin, while as measurements extended out into the mid-NE Atlantic (sample 19 in Fig. 5, corresponding to $-46.27^{\circ} \mathrm{E}, 36.26^{\circ} \mathrm{N}$ ), the natural contribution of sulfate peaked at $>90 \%$, although, more generally in this region, it was nearer to $75 \%$. For one third of the transect, the natural component was of the order of $70 \%$, reducing to $30-40 \%$ as measurements were taken close to Europe. It should be noted that $36^{\circ} \mathrm{N}$ is considerably south of the Mace Head latitude and is prone to both continental outflow from the US (over the north-west Atlantic) and Europe (over the NE Atlantic), much more so than the Mace Head latitude, due to contrasting meteorological patterns. For example, the most common clean marine air mass back trajectory arriving at Mace Head is that of a polar maritime air mass which enters into the Atlantic from Greenland and the sparsely populated north of Canada, while along the $36^{\circ} \mathrm{N}$ line, air masses enter the North Atlantic more from the polluted east coast of the US. Similarly, European continental outflow of pollution is more prevalent around southern Portugal, due to persistent high-pressure systems, compared to Mace Head which is more subject to eastwardly tracking cyclones. It was for precisely this reason of regular continental outflow that the ACE-2 (Aerosol Characterization Experiment) Lagrangian experiments started in this region (Johnson et al., 2000).

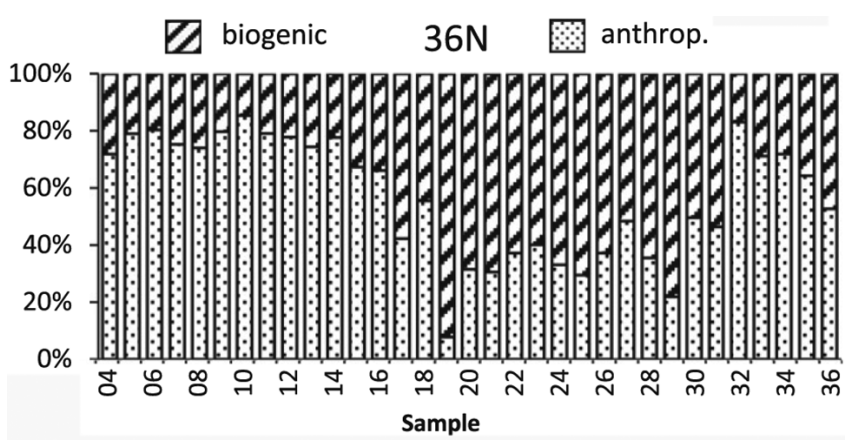

Figure 5. Nss-sulfate contributions from biogenic and anthropogenic sources during a west-east NE Atlantic transect at $36^{\circ} \mathrm{N}$, 1 May-15 June 2005. Sample 04 starts at $68.9^{\circ} \mathrm{W}$ and sample 36 ends at $8.3^{\circ} \mathrm{W}$. Source apportionment is achieved by sulfur isotope analysis. Figure adapted from Lin et al. (2012); copyright Elsevier (2012).

Ceburnis et al. (2011) also used isotope analysis to source apportion aerosol at Mace Head; however, their focus was on carbonaceous aerosols, using ${ }^{13} \mathrm{C}$ and ${ }^{14} \mathrm{C}$ isotopes simultaneously to quantify anthropogenic, marine biogenic, and terrestrial non-fossil carbon sources in submicron particles over the NE Atlantic. The contribution of marine biogenic carbon in marine air masses sampled by a sector-controlled system was, on average, $\sim 80 \%$, declining to $32 \%$ in nonmarine air (see Fig. 6). In the marine samples, the remaining sources were $14 \%$ fossil fuel and $7 \%$ non-fossil fuel. The uncertainty in a single isotope method, e.g. apportioning sources using only ${ }^{13} \mathrm{C}$, can be dramatically reduced using two isotopes simultaneously and an error minimisation approach as detailed by Ceburnis et al. (2011), thereby constraining not only the fractional contribution of sources, but also the corresponding isotope values of the sources themselves. The error minimisation approach leaves little degrees of freedom for the source isotope values and the fractional contribution of sources, resulting in the final uncertainty in the source isotope values of only $\pm 1 \%$ and the uncertainty in the fractional contribution of $\pm 5 \%$ (Ceburnis et al., 2011). An entrained FT (free troposphere) aerosol with a significant amount of non-marine OM (continental non-fossil or fossil fuel origin) would have inevitably been identified. The dual isotope approach reveals that only up to a maximum of $20 \%$ of such non-marine OM contributes to the total OM mass observed at Mace Head. Ceburnis et al. (2011) reported dual carbon isotope analysis of the total carbon, and, therefore, $\mathrm{BC}$ mass, however small, was part of the $21 \%$ of non-marine carbon $(\mathrm{OC}+\mathrm{BC})$. The variability of $\mathrm{BC}$, or more precisely $\mathrm{EBC}$, has been studied at high resolution with typical concentrations of $10-20 \mathrm{ng} \mathrm{m}^{-3}$ in sectored marine air masses occasionally reaching, but never exceeding, $50 \mathrm{ng} \mathrm{m}^{-3}$. It must be stressed that EBC can significantly overestimate BC concentration by up to $50 \%$ or more due to the reasons discussed above. There was, indeed, an OM component that 
Table 2. OM / EBC ratios for selected background marine locations and polluted regions. IMPROVE: Interagency Monitoring of Protected Visual Environments; OOMPH: Organics Over the ocean Modifying Particles in both Hemispheres; MBL: marine boundary layer.

\begin{tabular}{|c|c|c|}
\hline Location & $\mathrm{OM} / \mathrm{EBC}$ & References \\
\hline Amsterdam Island (South Indian Ocean) $)^{\mathrm{a}, 3}$ & 60 & Sciare et al. (2009) \\
\hline Point Reyes (North Pacific Ocean) ${ }^{\mathrm{a}, 2}$ & 15 & Sourced from IMPROVE \\
\hline Mace Head (North Atlantic) $)^{b, 1}$ & 28 & This study \\
\hline Mace Head (North Atlantic), OM plumes ${ }^{1}$ & 182 & Ovadnevaite et al. (2011b) \\
\hline OOMPH (South Atlantic) ${ }^{1}$ & 3.2 & Sourced from OOMPH \\
\hline McMurdo (Antarctica) $)^{\mathrm{a}, 3}$ & 2.5 & Mazzera et al. (2001) \\
\hline South-east Pacific, clean $\mathrm{MBL}^{\mathrm{c}, 1}$ & 10 & Shank et al. (2012) \\
\hline North-east coast of the US, south-westerly flow ${ }^{\mathrm{d}, 1}$ & 20 & Bates et al. (2005) \\
\hline North-east coast of the US, north-westerly flow ${ }^{\mathrm{d}, 1}$ & 34 & Bates et al. (2005) \\
\hline Canadian forest fires: fresh/aged ${ }^{1}$ & $85 / 25$ & Singh et al. (2010) \\
\hline South-west India ${ }^{1}$ & 1 & Quinn and Bates (2005) \\
\hline North-east Asia ${ }^{1}$ & 8 & Quinn and Bates (2005) \\
\hline Southern Africa ${ }^{1}$ & 8 & Haywood et al. (2003) \\
\hline Biomass burning & $2-17$ & Reid et al. (2005) \\
\hline North America ${ }^{\mathrm{a}, 2,3,4}$ & $2.63-2.91$ & Novakov et al. (2005) \\
\hline Europe $^{\mathrm{a}, 2,3,4}$ & $3.18-3.37$ & Novakov et al. (2005) \\
\hline China $^{\mathrm{a}, 2}$ & 3.29 & Novakov et al. (2005) \\
\hline India ${ }^{\mathrm{a}, 2,3,4}$ & 2.81 & Novakov et al. (2005) \\
\hline $\mathrm{Japan}^{\mathrm{a}, 2,3,4}$ & 1.81 & Novakov et al. (2005) \\
\hline
\end{tabular}

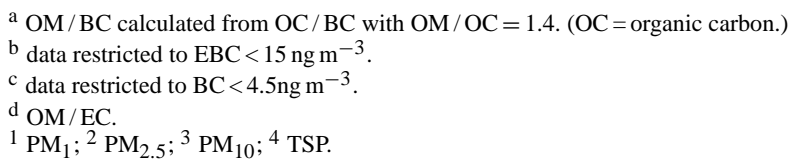

accompanied $\mathrm{BC}$ concentration, but there were only three samples for which the anthropogenic fraction of OM was unambiguously determined by isotope analysis. Ceburnis et al. (2011) reported (Table 2 of Ceburnis et al., 2011) that anthropogenic OM varied in the range of $13-24 \%$ or 24 $79 \mathrm{ng} \mathrm{m}^{-3}$ in clean marine air masses, and the variability could not be linked to specific air masses (Fig. 1 of Ceburnis et al., 2011).

Decesari et al. (2011) investigated the origin of the watersoluble organic carbon (WSOC) in marine aerosol samples collected at Mace Head, using the sector-controlled system described above, through proton nuclear magnetic resonance spectroscopy $\left({ }^{+} \mathrm{H}\right.$ NMR $)$. In order to disentangle the different components in the unresolved mixture that constitutes marine aerosol WSOC, they employed different factor analysis methods to extract spectral features on the basis of their variability between samples and interpreted them based on the correlation with known spectral profiles. In a five-factor solution, the statistical analysis identified one factor the spectral profile of which showed the most prominent aromatic groups and exhibited the strongest correlation with typical spectra of WSOC in polluted environments. The contribution of this factor was clearly highest for the samples collected outside the marine sector; it was added to the data set for comparison purposes (Fig. 7) and was attributed to an-

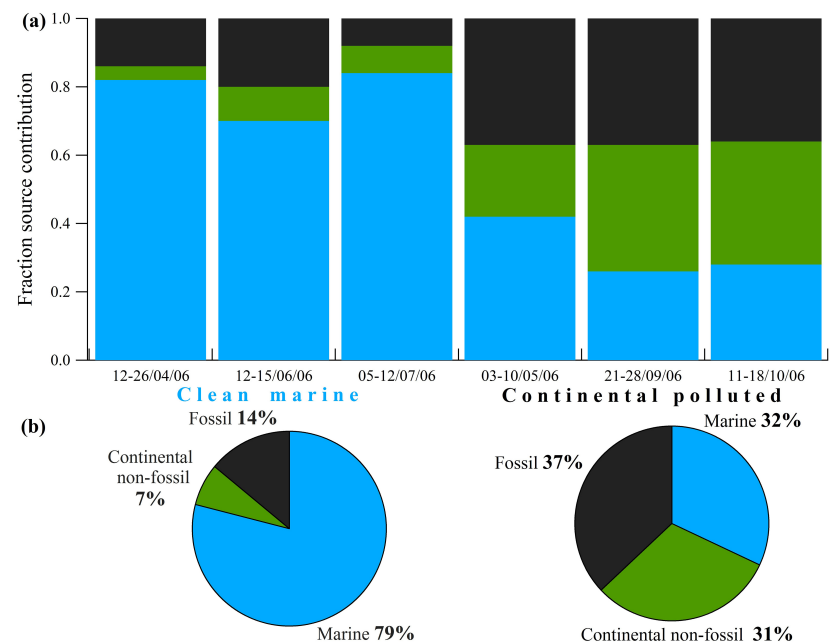

Figure 6. (a) Source contribution to organic matter in marine and polluted air samples in terms of fossil fuel carbon (black), nonfossil fuel continental carbon (dark green), and marine biogenic carbon (blue) sources; (b) same as (a) except for average source contributions over all samples for marine and continental air masses. Sourced from Ceburnis et al. (2011); copyright EGU (2011). 


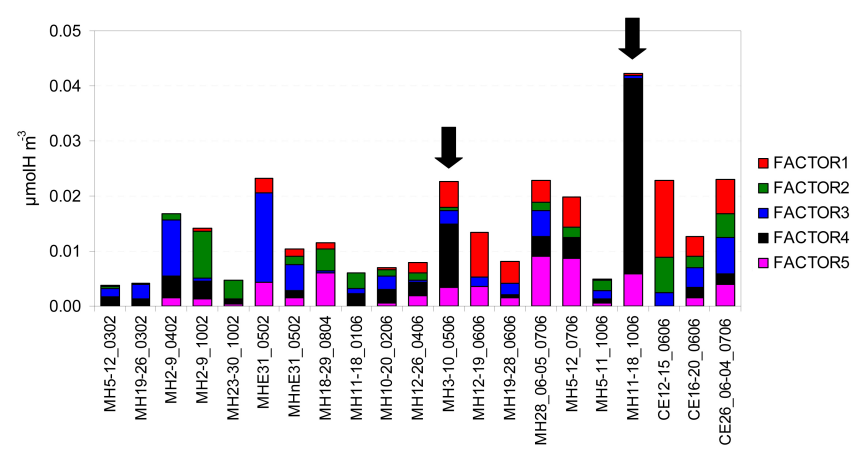

Figure 7. Contribution of the factors $\left(\mu \mathrm{M} \mathrm{m}^{-3}\right)$ identified in marine aerosol WSOC by Decesari et al. (2011). Factor 4 is associated with anthropogenic sources. The black arrows indicate samples collected outside the sector-controlled system, added to the data set for comparison purposes. Each bar represents one sample from Mace Head (MH) or the Celtic Explorer. MH5-12_0302 means Mace Head sample from 5 to 12 March 2002.

thropogenic sources. On the other hand, all the other factors presented spectral features consistent with a marine biogenic origin. The contribution of anthropogenic sources, as identified by factor analysis, in the data set investigated by Decesari et al. (2011) is $17 \%( \pm 13 \%)$, in good agreement with the results of Ceburnis et al. (2011).

The aforementioned studies use low-temporal-resolution sampling and subsequent off-line analysis. One drawback of such an approach is that maximum concentrations of particular aerosol species are smoothed out into long time-average values. With the advent of on-line aerosol mass spectrometry, real-time source apportionment of organic aerosol was made possible. Indeed, deployment of such measurement techniques by Ovadnevaite et al. (2011a, b) not only identified marine organic aerosol plumes with mass concentrations reaching $3.8 \mathrm{\mu g} \mathrm{m}^{-3}$, but also revealed a unique marine organic aerosol hydrocarbon fingerprint in contrast to anthropogenic hydrocarbons. It should be noted that the marine organic aerosol hydrocarbon pattern is dominated by $\mathrm{C}_{n} \mathrm{H}_{2 n-3}(m / z 39,53,67,81$, etc.; $\Delta=-2)$ and missing the class $\mathrm{C}_{n} \mathrm{H}_{2 n+1}(m / z 43,57,71$, etc.; $\Delta=2)$, which is indicative of refined hydrocarbons and predominant in the anthropogenic hydrocarbon mass spectrum. For the plume analysed, Fig. 8 illustrates that the air mass back trajectories advected over chlorophyll $a$ rich and stormy waters upwind, while Fig. 9 illustrates the unique mass spectral fingerprint associated with marine POM.

Further, this unique marine hydrocarbon species was highly correlated $\left(R^{2}>0.98\right)$ with an oxygenated hydrocarbon and suggested that approximately $98 \%$ of the organic aerosol was associated with organic sea spray, either partly oxidised or not oxidised at all. Such organic aerosol mass concentrations are not often encountered in marine air, and the concentrations rival those encountered in many urban regions; however, the mass spectral fingerprint and the ob-

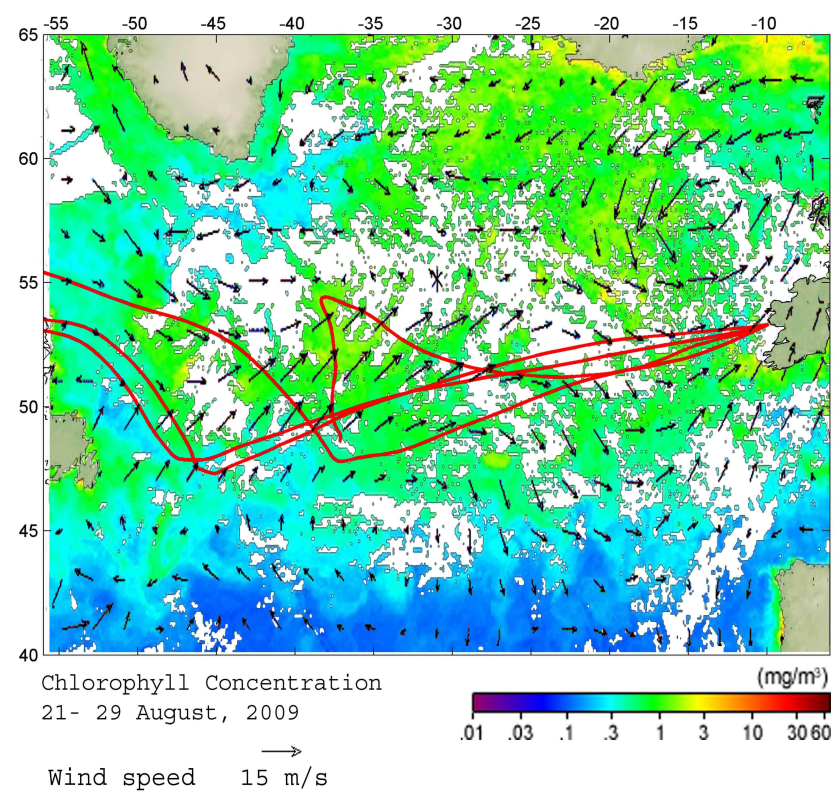

Figure 8. $96 \mathrm{~h}, 500 \mathrm{~m}$ height air mass back trajectories arriving at Mace Head during the organic plume event ending at 00:00, 06:00:, 12:00 and 18:00 UTC on the 16 August 2009. Aqua/MODIS chlorophyll $a$ concentration is given as an average for 21-29 August 2009 and corresponds to the closest coincident retrievable fields due to cloud contamination. The wind fields are represented as wind vectors (black arrows). Copyright American Geophysical Union, 2011; reprinted from Ovadnevaite et al. (2011a).

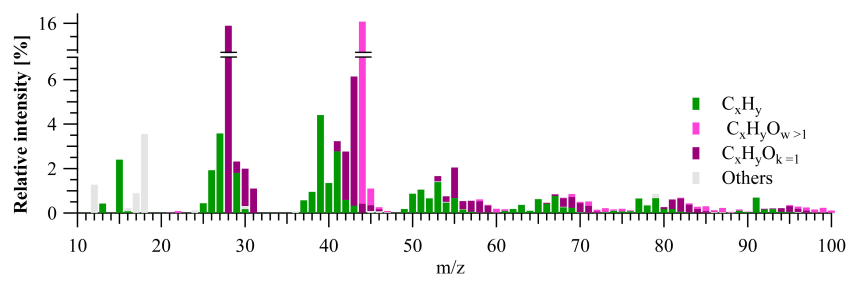

Figure 9. HR-ToF-AMS mass spectra (major organic family $\mathrm{CH}$ and $\mathrm{CHO}$, only) of marine organic plume detected on the 15-16 August 2009 at Mace head, Ireland. Copyright American Geophysical Union (2011); reprinted from Ovadnevaite et al. (2011a).

served OM / EBC ratio of 182, combined with the clearly marine air mass back trajectories, suggest that these organics are extremely unlikely to be anthropogenic in origin.

\subsection{Coastal sources and artefacts}

Apart from anthropogenic contamination, coastal contamination is the other main potential threat to the marine representativeness of marine-sector aerosol sampled at Mace Head, leading to artefacts, either in the form of enhanced surf zone production of sea spray and/or enhanced biological activity relative to open waters. In this section, we review the evidence for minimal coastal surf zone artefacts along with minimal coastal organic aerosol production. 

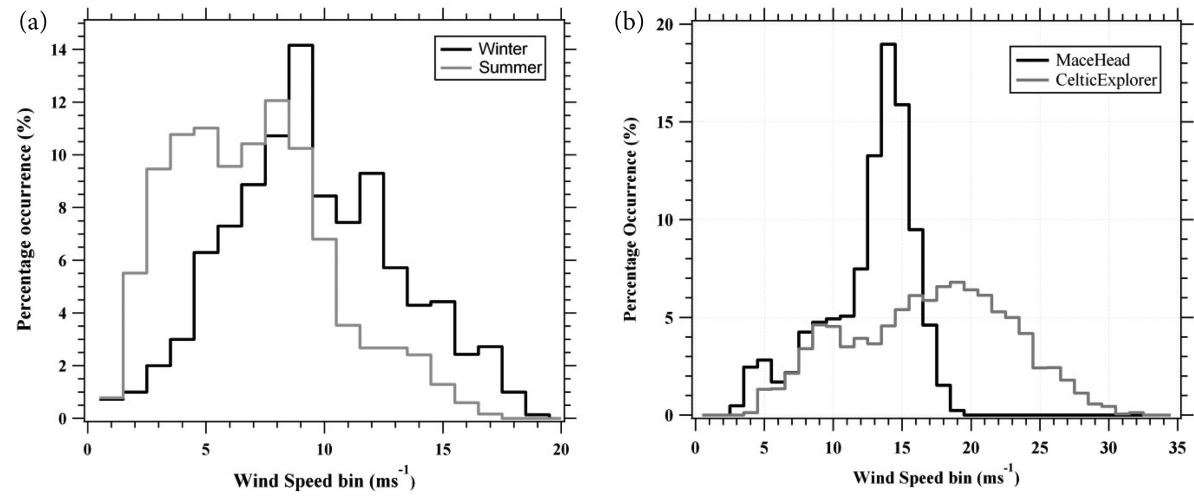

Figure 10. (a) Percentage frequency occurrence distribution for the year 2006 winter and summer seasons. Data reflect hourly averages over 3 months for each season. (b) Percentage frequency occurrence distribution for the Celtic Explorer MAP cruise storm offshore from Mace Head (dates: 20-22 June, 2006; latitude: $55-56.5^{\circ} \mathrm{N}$; longitude: $9.5-11^{\circ} \mathrm{W}$ ) compared to wind speed measured at Mace Head.

One of the first studies aimed at elucidating the contribution of surf-induced spray plumes, as opposed to breaking wave-induced spray plumes, was that of Kunz et al. (2002), who deployed a horizontally and vertically scanning lidar at Mace Head to examine the production and dispersion of seaspray plumes, demonstrating the formation and dispersion of surf-induced plumes from upwind rocks and islands, evolving to hundreds of metres in the vertical while transported a few kilometres horizontally from the source.

While the occurrence of surf-induced sea-spray plumes was clearly highlighted, the more complete and correct interpretation of the Kunz et al. (2002) study is that, at wind speeds below white-capping onset, surf-spray plumes from the upwind island are visible, given the absence of windwave breaking surf production, and that these plumes are readily mixed and dispersed vertically. Further, as the wind speed approaches moderate levels of $8 \mathrm{~m} \mathrm{~s}^{-1}$, the surf plumes produced upwind from Mace Head are increasingly indistinguishable from the breaking wind-wave spray plumes. Given that wind speeds are almost exclusively above the generally accepted whitecap threshold of $\sim 4 \mathrm{~m} \mathrm{~s}^{-1}$ (Monahan, 1971; Callaghan et al., 2008), this would suggest minimal impact of upwind surf plumes on aerosol measured at Mace Head. Figure 10 illustrates the wind speed frequency distribution at Mace Head during the winter (3 months: December, January, February) and summer (3 months: June, July, August) periods. Also shown is a 3-day period of high wind speed about $200 \mathrm{~km}$ upwind from Mace Head, measured during the MAP (marine aerosol production) cruise in June 2006, and the simultaneous wind speed at Mace Head. What is evident from the frequency distributions is that in summer, the distribution has two peaks at 5 and $8 \mathrm{~m} \mathrm{~s}^{-1}$, with $\sim 15 \%$ of wind speed occurring below the whitecap threshold of $4 \mathrm{~m} \mathrm{~s}^{-1}$. In winter, while also exhibiting a bimodal structure, the primary peak is at $9 \mathrm{~m} \mathrm{~s}^{-1}$ and the secondary peak is at $12 \mathrm{~m} \mathrm{~s}^{-1}$, with a $4 \%$ occurrence below the whitecap threshold. The upstream data during the MAP cruise illustrate the occurrence of a broad
$20 \mathrm{~m} \mathrm{~s}^{-1}$ frequency peak, extending to greater than $30 \mathrm{~m} \mathrm{~s}^{-1}$ during one particular 2-day summer storm. The simultaneous wind speeds measured at Mace Head exhibit a narrow frequency distribution peak at $14-15 \mathrm{~m} \mathrm{~s}^{-1}$. The point of this comparison is that there can be, at times, significantly higher winds offshore which potentially could produce sufficient sea spray to dominate over that produced locally at Mace Head, but, in general, wind speed measurements made at Mace Head agree well with the open-ocean wind speed in front of the station, as demonstrated by Gantt et al. (2011). Taking into account the wind speed frequency distribution in conjunction with the analysis in Kunz et al. (2002), one can only conclude minimal influence from offshore breaking surf. Indeed, Kunz et al. (2002) themselves conclude that "the influence of the background renders it difficult to quantify the effect of locally generated plumes on the concentrations at Mace Head in relation to wind direction and wind speed. In particular because during transport from the islands to the Mace Head station, vertical dispersion causes dilution of the primary aerosol, which brings the concentrations close to background levels. Hence the influence on the concentrations measured at Mace Head is relatively small, if any. An attempt to quantify this effect from direct measurements of aerosol concentrations at Mace Head, based on differences in concentrations between selected wind directions, showed no clear correlation. Also there was no obvious concentration enhancement when the wind was from the directions of the islands. At low wind speed, the concentrations of supermicron aerosol particles at Mace Head exhibited variability of not more than a factor of 2, and less in elevated wind speeds, although this cannot be directly linked to the offshore plumes. The concentrations of sub-micron aerosol particles are not affected [Kleefeld et al., 2002], in good agreement with other studies on surf aerosols [de Leeuw et al., 2000]."

Surf zone effects at the Mace Head shore are potentially more of a concern but also depend on sampling height. It should be acknowledged that, due to the rugged and modestly 
sloping foreshore at Mace Head, the breaking surf is limited to about a $10 \mathrm{~m}$ stretch. In this section, we will address the following questions: is submicron aerosol influenced by the local surf zone at Mace Head and are organic aerosols dominated by coastal contamination?

During the NAMBLEX (North Atlantic Marine Boundary Layer Experiment) experiment, Norton et al. (2006), using micrometeorological measurements, demonstrated some increase in surface drag between the 10 and $15 \mathrm{~m}$ sampling levels and attributed this to the top of the developing shore internal layer reaching this height; however, it should be noted that the increase was not very strong and could also be attributed to increased drag due to the laboratory buildings which were up to $8 \mathrm{~m}$ high and were located at the foot of the tower. During the same experiment, Coe et al. (2006) evaluated the gradient in particle number concentration and non-refractory aerosol chemical species concentration (e.g. nss sulfate, OM, ammonium, etc.) using an AMS switching between two sampling manifolds, sampling from 7 and $22 \mathrm{~m}$ heights on the main Mace Head $22 \mathrm{~m}$ sampling tower. While some differences were seen in total number concentration and were attributed to shoreline coastal nucleation events, no discernable difference was found amongst the non-refractory aerosol chemical species, suggesting no discernable gradient in the aerosol species measured over these heights. They also report that even particles in the 1 to $3 \mu \mathrm{m}$ range showed no evidence of the surface layer perturbing the concentration of particles at $7 \mathrm{~m}$ above ground level; this is the size range which would be almost exclusively dominated by sea salt.

The aforementioned study was expanded upon by Ceburnis et al. (2008) who deployed a Mace Head clean-sector gradient aerosol chemical flux experiment with the initial aim of quantifying the source of the WIOM aerosol component, previously attributed to sea-spray production by O'Dowd et al. (2004) and studies thereafter. In contrast to the Coe et al. (2006) height-switching gradient evaluation, which was conducted over a $15 \mathrm{~m}$ height difference on short timescales, Ceburnis et al. (2008) conducted gradient flux experiments over an extended $30 \mathrm{~m}$ gradient and over timescales of the order of a week. Such an approach can detect very subtle gradients for flux determining purposes, which would not be detectable in the gradient-switching approach. At this point it is appropriate to introduce the concepts of the flux footprint and the concentration. The flux footprint is the upwind area which contributes to the measured turbulent flux signal, while the concentration footprint is the upwind area which contributes to the concentration signal. Overall, the gradient method used at Mace Head revealed that the concentration gradient (not the concentration itself) is composed of emissions up to $5 \mathrm{~km}$ distant from the measurement location. All sources within that distance, starting from the surf zone and finishing with distant islands, can contribute to the concentration gradient, but the exact contribution of individual sources cannot be deduced from the gradient itself. Only additional estimates or experiments reveal the strength of those sources.
Geever et al. (2005) calculated the flux footprint from the Mace Head $22 \mathrm{~m}$ tower as starting $\sim 200 \mathrm{~m}$ upwind (to the west) of the tower, peaking $\sim 800-900 \mathrm{~m}$ offshore, and extending up to $7-8 \mathrm{~km}$ over the water. In contrast, the concentration footprint ranges from 10 to 100 times the flux footprint size, depending on the meteorological conditions.

Ceburnis et al. (2008) demonstrated that sea salt always possessed a negative gradient with height, pointing to a surface source, while nss sulfate and WSOM exhibited a positive gradient with height, pointing to a surface sink within the flux footprint and a source within or above the boundary layer or a source upwind of the flux footprint. While nss sulfate is exclusively formed through secondary processes, WSOM can either be secondary or processed primary WIOM formed upwind of the footprint. WIOM, on the other hand (Fig. 11), exhibited both positive and negative gradients, indicating both a surface source and a surface sink. These dual results leads to two important conclusions: the first is that WIOM in the clean marine air is indeed associated with POM sea-spray production (rather than long-range transport of pollution); the second is that WIOM can be produced upwind of the flux footprint and is not a surf zone or coastal artefact. The Ceburnis et al. (2008) experiment clearly indicates that at least the WIOM component of OM cannot be exclusively dismissed as a coastal artefact. What about WSOM and sea salt? The gradient profiles always demonstrate a surface source for sea salt, as is to be expected, and never a near-coast surface source for WSOM.

The potential for enhanced coastal primary production was further explored in a case study by Rinaldi et al. (2009), where a connected flow experiment between an upwind ship and shore-based measurements at Mace Head was reported. The comparison was limited to three sampling periods from 12 June to 5 July, covering between 36 and $80 \mathrm{~h}$ within each of these sampling periods, depending on the sample, with the Research Vessel Celtic Explorer operating 200$350 \mathrm{~km}$ upwind of Mace Head. The aim of the comparison was not to determine whether what was measured offshore was identical to that measured at Mace Head since such a scenario would represent an unrealistic steady-state scenario between source, evolution, and sink processes over large areas when it is clear that there are differences in both meteorology and ocean-surface composition over such areas. Furthermore, it was to evaluate whether there was a consistently higher mass contribution from particular aerosol chemical species which could be attributed to coastal production artefacts at Mace Head. The comparison cases revealed comparable, if not even higher, offshore concentrations for nss sulfate, WSOM, WIOM, and MSA. Sea salt, in supermicron sizes, exhibited $40 \%$ higher mass at Mace Head, with no discernable differences for submicron sea salt. The whole motivation of this paper is to demonstrate that submicron $\mathrm{OM}$, in particular, originates predominantly from non-surf-zone marine sources. It has previously been shown that breaking surf preferentially produces supermicron salt 


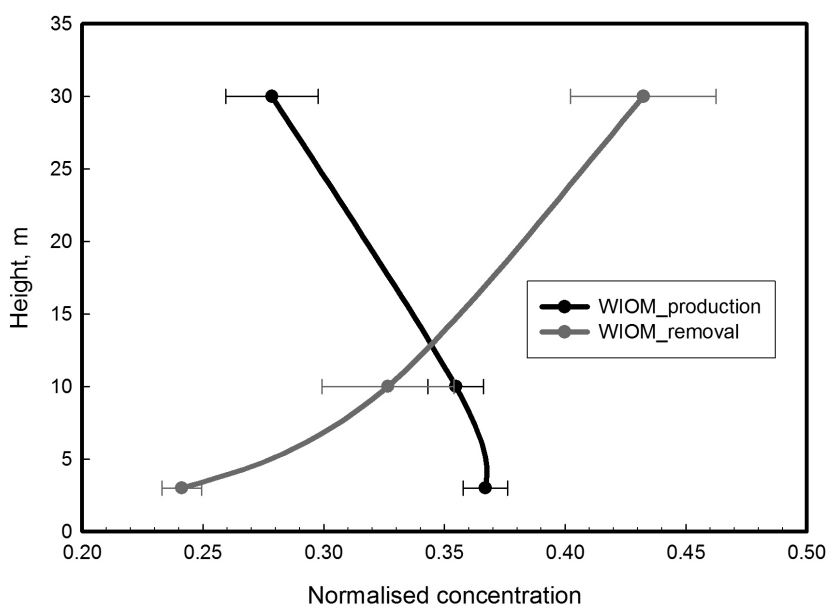

Figure 11. Concentration gradients of PM1 water-insoluble organic matter (WIOM) obtained from 3, 10, and $22 \mathrm{~m}$ heights. The positive gradient case represents a surface sink, while the negative gradient with height represents a surface source.

particles (de Leeuw et al., 2000), suggesting that part of the difference in supermicron sea-salt mass is due to surf production in the coastal zone; however, some of the enhanced mass observed can be attributed to the wind speed at Mace Head, which was 1.8 times higher than the offshore wind encountered by the ship for that particular comparison sample. The above studies suggest that there is no discernable enhancement in submicron sea salt or primary organic sea spray as a result of surf zone breaking waves at sampling heights of $7 \mathrm{~m}$ or higher.

Moreover, a recent study utilised AMS-derived sea-salt mass concentrations (Ovadnevaite et al., 2012) to develop a submicron sea-salt mass source function for wind speeds up to $26 \mathrm{~m} \mathrm{~s}^{-1}$, at which $10 \mathrm{~m}$ height sea-salt mass concentrations reached a maximum of $2.5 \mu \mathrm{g} \mathrm{m}^{-3}$. Three well-known source functions - those of Martensson et al. (2003), Fuentes et al. (2010b), and Gong (2003) - were applied to predict the resulting mass concentrations for the observed boundary layer height and 2-day wind speed evolution, all of which were found to predict significantly, and unrealistically, higher mass concentrations that resulted in 3-10 times higher concentrations compared to the Mace Head source function. If Mace Head was subjected to notable coastal submicron surf contamination, one might anticipate the actual mass measurements being substantially greater that the predicted values; however, it was exactly the opposite.

Facchini et al. (2008b) also presented results conclusively confirming that the WIOM component of marine air is associated with primary sea spray. In doing so, they illustrated that the WIOM/sea-salt ratio fingerprint as a function of size was almost identical for samples collected in air at Mace Head, in air offshore on the Celtic Explorer, and in bubblebursting laboratory experiments on board the Celtic Explorer (Fig. 12). The similarity in the ratio and the size fingerprint confirms that, at least, the relative proportions of WIOM as a function size are not influenced by coastal artefacts.

\subsection{Free-troposphere aerosol}

The free troposphere is both a source and a sink of marine boundary layer aerosol via entrainment and detrainment processes and can influence both the microphysics of the size distributions and the physico-chemical properties of the resulting aerosol. Hoell et al. (2000), examined the dominant factors driving the evolution of air masses and aerosol populations as they advected over the Atlantic during the ACE-2 Lagrangian studies and determined, under certain conditions of rapid changes to the boundary layer height (i.e. timescales of less than $24 \mathrm{~h}$ ), that boundary layer aerosol could be notably diluted or enhanced depending on the BL-FT (boundary layer-free troposphere) gradients. They also acknowledge that the assessment of BL-FT exchange is very complex due to a multi-layer boundary layer structure, as also described in Kunz et al. (2002). For example, taking a typical entrainment rate of $0.5 \mathrm{~cm} \mathrm{~s}^{-1}$ and making the case for the whole well-mixed $1000 \mathrm{~m} \mathrm{BL}$ air being replaced by a $1000 \mathrm{mFT}$ clean layer (leading to dilution of the BL) or a polluted layer (leading to very notable BL pollution) is not very revealing in terms of source apportionment, due to complex coupling or decoupling of layers within the BL; for the same reason, it is unlikely to be accurate in practice. Nevertheless, entrainment is a reality and can impact on $\mathrm{BL}$ or marine aerosol production quantification and physicochemical characterisation in a number of ways. If the FT is pristine (with negligible anthropogenic/continental influence), the impact on BL aerosol will be mostly to dilute absolute concentrations while maintaining the marine aerosol chemical signature. Size distribution changes are more likely as the FT aerosol is more prone to possess a higher number of smaller particles, contributing relatively more to particle number rather than chemical mass. If the FT aerosol contains polluted layer, such as can be associated with longrange transport of pollution plumes (e.g. anthropogenic or biomass burning related), then the marine aerosol chemical signature will change in conjunction with microphysical or size distribution changes.

If dilution by a pristine FT layer dominates BL-FT exchange, what does this mean for the integrity of marine aerosol characterisation at Mace Head? Given that the marine aerosol burden represents an instantaneous balance between sources and sinks, the characterisation of the aerosol physico-chemical properties can be regarded as representative of marine aerosol for that specific production-loss scenario. On the other hand, if there is a significant aerosol burden in the FT, entrainment of this aerosol will also alter the chemical properties of aerosol measured in the BL. Separating out such a non-marine signature, or isolating the marine component, benefits from sophisticated sampling techniques, such as direct flux measurements, sophisticated 

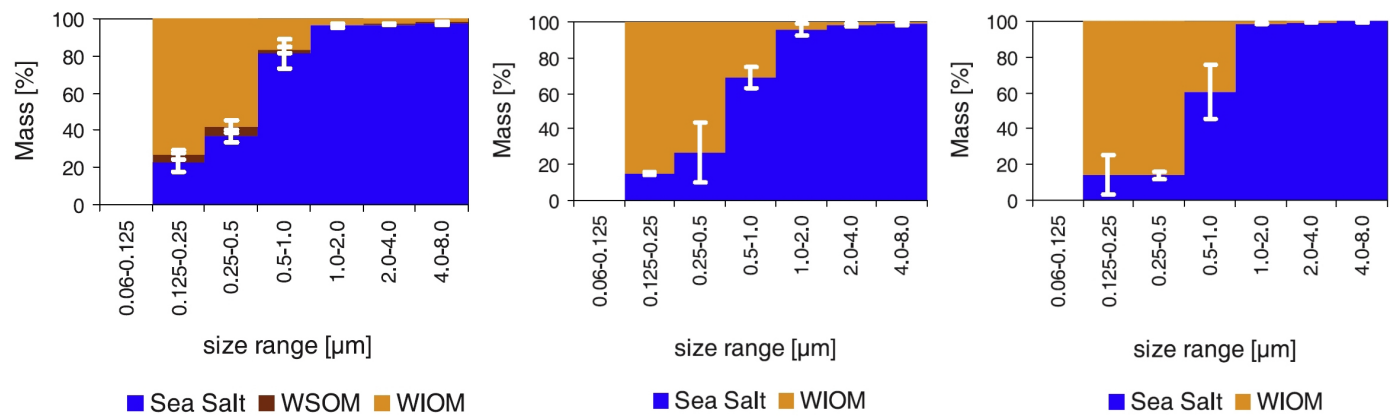

Figure 12. WIOM/sea-salt percentage mass contributions as a function of size for laboratory-based bubble-bursting experiments on the Celtic Explorer (left), from air samples collected at Mace Head (middle), and from air samples onboard the RV Celtic Explorer (right). Note that while the OM percentage mass contribution illustrates a dominance of OM in submicron sizes, it should be noted that approximately $50 \%$ of the total OM mass resides in the supermicron sizes. Copyright American Geophysical Union (2008); reprinted from Facchini et al. (2008b).

off-line analytical methods such as H-NMR and isotope analysis, or on-line aerosol mass spectrometry. What did such approaches yield in terms of selectively characterising marine aerosol abundance and properties at Mace Head or the contribution of non-marine sources to aerosol measured in the region? Direct fluxes revealed that the WIOM was surfaced-sourced and primary in origin. In addition, the good agreement between fluxes derived from gradient methods and concentration methods suggests that the more extensive concentration-based fluxes are not influenced by entrainment. In terms of chemical finger printing or source apportionment, both the HNMR (Decesari et al., 2011) and isotope analysis (Ceburnis et al., 2011) were capable of identifying the non-marine aerosol component, while aerosol mass spectrometry was able to elucidate distinct marine biogenic $\mathrm{OM}$ markers and to identify unique marine aerosol tracers of primary marine spray rather than combustion or anthropogenic sources (Ovadnevaite et al., 2011b). Over oceanic regions such as the North Atlantic, boundary layer height is typically 1500 to $2000 \mathrm{~m}$ so the trajectories do not necessarily reflect a significant FT entrainment. However, MODIS fire counts for the period presented in Ovadnevaite et al. (2011b) indicated no connection with fires and certainly none over Canada. In addition, HTDMA (Humidity Tandem Differential Mobility Analyser) growth factor measurements revealed organic particles with much lower hygroscopicity than reported in relation to aged forest fire particulate emissions. In terms of distinguishing $\mathrm{OM}$ from marine sources from that associated with biomass burning smoke, for example, the marine organic fragmentation pattern was distinctly different from that of aged biomass burning organic aerosol (BBOA) with a coefficient of determination $\left(R^{2}\right)$ between the two mass spectra equal to 0.22. Moreover, major BBOA markers $(\mathrm{m} / \mathrm{z} 60021$ and $m / z 73029$ ), fragments characteristic of levoglucosan (a tracer for cellulose pyrolysis), as well as typical BBOA ion series of $\mathrm{C}_{\mathrm{n}} \mathrm{H}_{2 \mathrm{n}+1}(m / z 43,57,71$, etc.; $\Delta=2)$ were all absent in the primary marine OA (organic aerosol), but different fragments such as $m / z 39\left(\mathrm{C}_{3} \mathrm{H}_{3}^{+}\right), m / z 53\left(\mathrm{C}_{4} \mathrm{H}_{5}^{+}\right), m / z$
$43\left(\mathrm{C}_{2} \mathrm{H}_{3} \mathrm{O}^{+}\right), m / z 55\left(\mathrm{C}_{3} \mathrm{H}_{3} \mathrm{O}^{+}\right), m / z 44\left(\mathrm{CO}_{2}^{+}\right)$, and $m / z$ $99\left(\mathrm{C}_{5} \mathrm{H}_{7} \mathrm{O}^{+}\right)$, were prominent. Such a distinct mass spectrum shows a different marine organic plume origin than that of aged BBOA. Aging of BBOA would change the oxidation level of OM; however, there is no indication that it could possibly add new fragments or completely lose the BBOA markers (Jolleys et al., 2012). The use of mass spectral fingerprint analysis to source apportion the marine aerosol arriving at Mace Head suggests that Canadian biomass burning plumes observed over the east coast of North America by Clarke et al. (2007) do not detectably impact on the marine aerosol properties reported under our sampling criteria.

\section{Discussion and conclusions}

Patterns of biological productivity are different from ocean to ocean; this is especially evident when comparing chlorophyll $a$ concentration fields in the contrasting South Pacific and North Atlantic Oceans, the former being more patchy and homogenously distributed throughout the year, while the latter experiences a high seasonal variability, but with concentrations much more uniform over the area. Moreover, the chlorophyll $a$ concentrations over the South Pacific are consistently lower (monthly concentrations varying by $\sim 0.1 \mathrm{mg} \mathrm{m}^{-3}$ with some peak concentrations of $0.4 \mathrm{mg} \mathrm{m}^{-3}$ around the equator) than those seen in the North Atlantic (where monthly average concentrations range from $\sim 0.2 \mathrm{mg} \mathrm{m}^{-3}$ for low biological activity periods to $\sim 0.7 \mathrm{mg} \mathrm{m}^{-3}$ for high biological activity periods). Overall, the biomass abundance is far greater in the North Atlantic compared to the equatorial and South Pacific, and the higher chlorophyll $a$ concentrations encountered by Shank et al. (2012) over the Pacific are at the lower end of the values reported over the NE Atlantic summarised in this paper. Consequently, it is no surprise that the $\mathrm{OM}$ concentrations observed by Shank et al. (2012) are at the lower end of the concentrations observed at Mace Head. 
What is striking in the difference between the two data sets is that the relationship between OM and BC for BC mass less than $15 \mathrm{ng} \mathrm{m}^{-3}$ in Shank et al. (2012) is highly correlated $\left(R^{2}=0.66\right)$, while neither OM vs. BC, or in this case $\mathrm{EBC}$, at concentrations between $0-15 \mathrm{ng} \mathrm{m}^{-3}$ and $15-50 \mathrm{ng} \mathrm{m}^{-3}$ measured at Mace Head are correlated $\left(R^{2}=0.006\right.$ and $R^{2}=0.046$, respectively), despite peak OM mass concentrations reaching an order of magnitude higher in the Mace $\mathrm{Head} /$ Atlantic. In addition, the $\mathrm{OM} / \mathrm{BC}$ ratios are at between 3 and 100 times larger over the Atlantic than the Pacific. The parameters most comparable in the Shank et al. (2012) Pacific studies and those at Mace Head are the OM-BC absolute mass concentrations, their intercorrelations, and their relative mass ratios; however, the intercomparison of these parameters point to the conclusion that even OM present at Mace Head (NE Atlantic) at concentrations more than an order of magnitude higher than in the Pacific can be regarded as almost exclusively naturally biogenic, while the $\mathrm{OM}$ at similar low levels of BC over the Pacific can be regarded as predominantly anthropogenic.

Reviewing the other evidence available to elucidate the pedigree of the maritime nature of marine aerosol sampled under Mace Head clean-air criteria, we can summarise the following:

- Over 25 years, anthropogenic sulfate aerosol concentrations have reduced to $20-25 \%$ of their initial values so that the anthropogenic sulfate contamination of the NE Atlantic has greatly reduced to a similar extent.

- Marine-sector sampling based on wind direction alone is subject to significant anthropogenic contamination from recirculating European continental air; additional criteria such as $\mathrm{CN}$ and $\mathrm{BC}$ concentrations are required.

- Carbon isotope and HNMR analysis show that 80\% of OM measured at Mace Head according to marineair criteria is marine biogenic in origin, suggesting an upper limit of $20 \%$ continental and fossil-fuel-sourced total carbon mass.

- Aerosol mass spectral analysis reveals the clear dominance $(\sim 97 \%)$ of a unique marine POM aerosol type during organic sea-spray plumes.

- Comparison of aerosol-speciated chemical mass at Mace Head and in connected flow upwind and offshore shows no evidence of coastal enhancement of primary aerosol in submicron sizes.

- Gradient measurements between 7 and $22 \mathrm{~m}$ at Mace Head, using an aerosol mass spectrometer, revealed no discernible difference and, consequently, no coastal, surf zone or tidal effects.

- Gradient flux measurements demonstrate that OM production is not unique to the coastal zone.
Consolidating the above statements, one can conclude that, for submicron marine aerosol sampled under the Mace Head clean marine air sampling criteria, there are no discernable coastal artefacts and that the anthropogenic contribution to $\mathrm{OM}$ associated with marine aerosol under these criteria ranges from $3 \%$ to a maximum of $20 \%$. The dependency of the anthropogenic contribution to $\mathrm{OM}$ as a function of meteorology must be elucidated through further studies on the interaction between marine meteorology and marine biological productivity, ocean-surface water enrichment as a function of wind stress and white capping, temperature influences on sea-spray production, air mass origin, precipitation removal, long-range transport, and changing anthropogenic emissions. Such studies should comprise long-term and continuous measurements of aerosol physicochemical properties, aerosol production and removal, and measurements of both meteorological and biological processes influencing the aerosol life cycle given the dependency of the relative contribution on so many environmental parameters. Such a longterm and continuous measurement programme requires an observation platform fit for purpose, and the arguments presented above, we contend, demonstrate that Mace Head is indeed such a fit-for-purpose platform.

Acknowledgements. This work was supported by the EPA Ireland, HEA, EC (under MAP, EUCAARI, EUSAAR and ACTRIS), SFI, and ESA-SSE-OSSA.

Edited by: K. Carslaw

\section{References}

Bates, T. S., Quinn, P. K., Coffman, D. J., Johnson, J. E., and Middlebrook, A. M.: Dominance of organic aerosols in the marine boundary layer over the Gulf of Maine during NEAQS 2002 and their role in aerosol light scattering, J. Geophys. Res.-Atmos., 110, D18202, doi:10.1029/2005jd005797, 2005.

Callaghan, A., de Leeuw, G., Cohen, L., and O'Dowd, C. D.: Relationship of oceanic whitecap coverage to wind speed and wind history, Geophys. Res. Lett., 35, L23609, doi:10.1029/2008g1036165, 2008.

Cavalli, F., Facchini, M. C., Decesari, S., Mircea, M., Emblico, L., Fuzzi, S., Ceburnis, D., Yoon, Y. J., O’Dowd, C. D., Putaud, J. P., and Dell'Acqua, A.: Advances in characterization of size-resolved organic matter in marine aerosol over the North Atlantic, J. Geophys. Res.-Atmos., 109, D24215, doi:10.1029/2004jd005137, 2004.

Ceburnis, D., O’Dowd, C. D., Jennings, G. S., Facchini, M. C., Emblico, L., Decesari, S., Fuzzi, S., and Sakalys, J.: Marine aerosol chemistry gradients: Elucidating primary and secondary processes and fluxes, Geophys. Res. Lett., 35, L07804, doi:10.1029/2008g1033462, 2008.

Ceburnis, D., Garbaras, A., Szidat, S., Rinaldi, M., Fahrni, S., Perron, N., Wacker, L., Leinert, S., Remeikis, V., Facchini, M. C., Prevot, A. S. H., Jennings, S. G., Ramonet, M., and O'Dowd, C. D.: Quantification of the carbonaceous matter origin in sub- 
micron marine aerosol by ${ }^{13} \mathrm{C}$ and ${ }^{14} \mathrm{C}$ isotope analysis, Atmos. Chem. Phys., 11, 8593-8606, doi:10.5194/acp-11-85932011, 2011.

Charlson, R. J., Lovelock, J. E., Andreae, M. O., and Warren, S. G.: Oceanic phytoplankton, atmospheric sulfur, cloud albedo and climate, Nature, 326, 655-661, 1987.

Clarke, A., McNaughton, C., Kapustin, V., Shinozuka, Y., Howell, S., Dibb, J., Zhou, J., Anderson, B., Brekhovskikh, V., Turner, H., and Pinkerton, M.: Biomass burning and pollution aerosol over North America: Organic components and their influence on spectral optical properties and humidification response, J. Geophys. Res., 112, D12S18, doi:10.1029/2006JD007777, 2007.

Coe, H., Allan, J. D., Alfarra, M. R., Bower, K. N., Flynn, M. J., McFiggans, G. B., Topping, D. O., Williams, P. I., O’Dowd, C. D., Dall'Osto, M., Beddows, D. C. S., and Harrison, R. M.: Chemical and physical characteristics of aerosol particles at a remote coastal location, Mace Head, Ireland, during NAMBLEX, Atmos. Chem. Phys., 6, 3289-3301, doi:10.5194/acp-6-3289-2006, 2006.

Cooke, W. F., Jennings, S. G., and Spain, T. G.: Black carbon measurements at Mace Head, 1989-1996, J. Geophys. Res.-Atmos., 102, 25339-25346, doi;10.1029/97jd01430, 1997.

Dall'Osto, M., Ceburnis, D., Martucci, G., Bialek, J., Dupuy, R., Jennings, S. G., Berresheim, H., Wenger, J., Healy, R., Facchini, M. C., Rinaldi, M., Giulianelli, L., Finessi, E., Worsnop, D., Ehn, M., Mikkilä, J., Kulmala, M., and O'Dowd, C. D.: Aerosol properties associated with air masses arriving into the North East Atlantic during the 2008 Mace Head EUCAARI intensive observing period: an overview, Atmos. Chem. Phys., 10, 8413-8435, doi:10.5194/acp-10-8413-2010, 2010.

Decesari, S., Finessi, E., Rinaldi, M., Paglione, M., Fuzzi, S., Stephanou, E. G., Tziaras, T., Spyros, A., Ceburnis, D., O'Dowd, C., Dall'Osto, M., Harrison, R. M., Allan, J., Coe, H., and Facchini, M. C.: Primary and secondary marine organic aerosols over the North Atlantic Ocean during the MAP experiment, J. Geophys. Res.-Atmos., 116, D22210, doi:10.1029/2011jd016204, 2011.

de Leeuw, G., Neele, F. P., Hill, M., Smith, M. H., and Vignali, E.: Production of sea spray aerosol in the surf zone, J. Geophys. Res.-Atmos., 105, 29397-29409, 2000.

de Leeuw, G., Andreas, E. L., Anguelova, M. D., Fairall, C. W., Lewis, E. R., O’Dowd, C., Schulz, M., and Schwartz, S. E.: Production flux of sea spray aerosol, Rev. Geophys., 49, Rg2001, doi:10.1029/2010rg000349, 2011.

Facchini, M. C., Decesari, S., Rinaldi, M., Carbone, C., Finessi, E., Mircea, M., Fuzzi, S., Moretti, F., Tagliavini, E., Ceburnis, D., and O'Dowd, C. D.: Important Source of Marine Secondary Organic Aerosol from Biogenic Amines, Environ. Sci. Technol., 42, 9116-9121, doi:10.1021/Es8018385, 2008a.

Facchini, M. C., Rinaldi, M., Decesari, S., Carbone, C., Finessi, E., Mircea, M., Fuzzi, S., Ceburnis, D., Flanagan, R., Nilsson, E. D., de Leeuw, G., Martino, M., Woeltjen, J., and O'Dowd, C. D.: Primary submicron marine aerosol dominated by insoluble organic colloids and aggregates, Geophys. Res. Lett., 35, L17814, doi:10.1029/2008gl034210, 2008b.

Fuentes, E., Coe, H., Green, D., de Leeuw, G., and McFiggans, G.: Laboratory-generated primary marine aerosol via bubblebursting and atomization, Atmos. Meas. Tech., 3, 141-162, doi:10.5194/amt-3-141-2010, 2010a.
Fuentes, E., Coe, H., Green, D., de Leeuw, G., and McFiggans, G.: On the impacts of phytoplankton-derived organic matter on the properties of the primary marine aerosol - Part 1: Source fluxes, Atmos. Chem. Phys., 10, 9295-9317, doi:10.5194/acp-10-92952010, 2010b.

Gantt, B., Meskhidze, N., Facchini, M. C., Rinaldi, M., Ceburnis, D., and O'Dowd, C. D.: Wind speed dependent size-resolved parameterization for the organic mass fraction of sea spray aerosol, Atmos. Chem. Phys., 11, 8777-8790, doi:10.5194/acp-11-87772011, 2011.

Geever, M., O’Dowd, C. D., van Ekeren, S., Flanagan, R., Nilsson, E. D., de Leeuw, G., and Rannik, U.: Submicron sea spray fluxes, Geophys. Res. Lett., 32, L15810, doi:10.1029/2005gl023081, 2005.

Gong, S. L.: A parameterization of sea-salt aerosol source function for sub- and super-micron particles, Glob. Biogeochem. Cycle, 17, 1097, doi:10.1029/2003gb002079, 2003.

Hansen, A. D. A., Bodhaine, B. A., Dutton, E. G., and Schnell, R. C.: Aerosol black carbon measurements at the South Pole Initial results, 1986-1987, Geophys. Res. Lett., 15, 1193-1196, doi:10.1029/GL015i011p01193, 1988.

Hara, K., Osada, K., Yabuki, M., Hayashi, M., Yamanouchi, T., Shiobara, M., and Wada, M.: Measurement of black carbon at Syowa station, Antarctica: seasonal variation, transport processes and pathways, Atmos. Chem. Phys. Discuss., 8, 9883-9929, doi:10.5194/acpd-8-9883-2008, 2008.

Haywood, J. M., Osborne, S. R., Francis, P. N., Keil, A., Formenti, P., Andreae, M. O., and Kaye, P. H.: The mean physical and optical properties of regional haze dominated by biomass burning aerosol measured from the C-130 aircraft during SAFARI 2000, J. Geophys. Res.-Atmos., 108, 8473, doi:10.1029/2002jd002226, 2003.

Hoell, C., O’Dowd, C., Osborne, S., and Johnson, D.: Time-scale analysis of marine boundary layer aerosol evolution: Lagrangian case studies under clean and polluted cloudy conditions, Tellus Ser. B-Chem. Phys. Meteorol., 52, 423-438, 2000.

Jennings, S. G., Kleefeld, C., O’Dowd, C. D., Junker, C., Spain, T. G., O'Brien, P., Roddy, A. F., and O'Connor, T. C.: Mace head atmospheric research station characterization of aerosol radiative parameters, Boreal Environ. Res., 8, 303-314, 2003.

Johnson, D. W., Osborne, S., Wood, R., Suhre, K., Johnson, R., Businger, S., Quinn, P. K., Wiedensohler, A., Durkee, P. A., Russell, L. M., Andreae, M. O., O’Dowd, C., Noone, K. J., Bandy, B., Rudolph, J., and Rapsomanikis, S.: An overview of the Lagrangian experiments undertaken during the North Atlantic regional Aerosol Characterisation Experiment (ACE-2), Tellus Ser. B-Chem. Phys. Meteorol., 52, 290-320, 2000.

Jolleys, M. D., Coe, H., McFiggans, G., Capes, G., Allan, J. D., Crosier, J., Williams, P. I., Allen, G., Bower, K. N., Jimenez, J. L., Russell, L. M., Grutter, M., and Baumgardner, D.: Characterizing the Aging of Biomass Burning Organic Aerosol by Use of Mixing Ratios: A Meta-analysis of Four Regions, Environ. Sci. Technol., 46, 13093-13102, doi:10.1021/es302386v, 2012.

Junker, C., Jennings, S. G., and Cachier, H.: Aerosol light absorption in the North Atlantic: trends and seasonal characteristics during the period 1989 to 2003, Atmos. Chem. Phys., 6, 1913-1925, doi:10.5194/acp-6-1913-2006, 2006.

Keene, W. C., Maring, H., Maben, J. R., Kieber, D. J., Pszenny, A. A. P., Dahl, E. E., Izaguirre, M. A., Davis, A. J., Long, M. 
S., Zhou, X. L., Smoydzin, L., and Sander, R.: Chemical and physical characteristics of nascent aerosols produced by bursting bubbles at a model air-sea interface, J. Geophys. Res.-Atmos., 112, D21202, doi:10.1029/2007jd008464, 2007.

King, S. M., Butcher, A. C., Rosenoern, T., Coz, E., Lieke, K. I., de Leeuw, G., Nilsson, E. D., and Bilde, M.: Investigating Primary Marine Aerosol Properties: CCN Activity of Sea Salt and Mixed Inorganic-Organic Particles, Environ. Sci. Technol., 46, 1040510412, doi:10.1021/es300574u, 2012.

Kleefeld, C., O’Dowd, C. D., O’Riely, S., Jennings, S. G., Aalto, P., Becker, E., Kunz, G., and de Leeuw, G.: The relative scattering of sub and super micron particles to aerosol light scattering in the marine boundary layer (MBL), J. Geophys. Res., 107, 8103, doi:10.1029/2000JD000262, 2002.

Kunz, G. J., de Leeuw, G., Becker, E., and O’Dowd, C. D.: Lidar observations of atmospheric boundary layer structure and sea spray aerosol plumes generation and transport at Mace Head, Ireland (PARFORCE experiment), J. Geophys. Res.-Atmos., 107, 8106, doi:10.1029/2001jd001240, 2002.

Lin, C. T., Baker, A. R., Jickells, T. D., Kelly, S., and Lesworth, T.: An assessment of the significance of sulphate sources over the Atlantic Ocean based on sulphur isotope data, Atmos. Environ., 62, 615-621, doi:10.1016/j.atmosenv.2012.08.052, 2012.

Martensson, E. M., Nilsson, E. D., de Leeuw, G., Cohen, L. H., and Hansson, H. C.: Laboratory simulations and parameterization of the primary marine aerosol production, J. Geophys. Res.-Atmos., 108, 4297, doi:10.1029/2002jd002263, 2003.

Mazzera, D. M., Lowenthal, D. H., Chow, J. C., Watson, J. G., and Grubisic, V.: $\mathrm{PM}_{10}$ measurements at McMurdo Station, Antarctica, Atmos. Environ., 35, 1891-1902, doi:10.1016/s13522310(00)00409-x, 2001.

McArdle, N., Liss, P., and Dennis, P.: An isotopic study of atmospheric sulphur at three sites in Wales and at Mace Head, Eire, J. Geophys. Res.-Atmos., 103, 31079-31094, doi:10.1029/98jd01664, 1998.

Monahan, E. C.: Oceanic whitecaps, J. Phys. Oceanogr., 1, 139144, 1971.

Norton, E. G., Vaughan, G., Methven, J., Coe, H., Brooks, B., Gallagher, M., and Longley, I.: Boundary layer structure and decoupling from synoptic scale flow during NAMBLEX, Atmos. Chem. Phys., 6, 433-445, doi:10.5194/acp-6-433-2006, 2006.

Novakov, T., Menon, S., Kirchstetter, T. W., Koch, D., and Hansen, J. E.: Aerosol organic carbon to black carbon ratios: Analysis of published data and implications for climate forcing, J. Geophys. Res.-Atmos., 110, D21205, doi:10.1029/2005jd005977, 2005.

O'Connor, T. C., Jennings, S. G., and O’Dowd, C. D.: Highlights of fifty years of atmospheric aerosol research at Mace Head, Atmos. Res., 90, 338-355, doi:10.1016/j.atmosres.2008.08.014, 2008.

O'Dowd, C. D. and de Leeuw, G.: Marine aerosol production: a review of the current knowledge, Philosophical Transactions of the Royal Society a-Mathematical Physical and Engineering Sciences, 365, 1753-1774, doi:10.1098/rsta.2007.2043, 2007.

O'Dowd, C. D. and Smith, M. H.: Physicochemical properties of aerosols over the northeast Atlantic: Evidence for wind-speedrelated submicron sea-salt aerosol production, J. Geophys. Res.Atmos., 98, 1137-1149, doi:10.1029/92JD02302, 1993.

O'Dowd, C. D., Lowe, J. A., Smith, M. H., Davison, B., Hewitt, N., and Harrison, R. M.: Biogenic sulphur emissions and inferred non-sea-salt-sulphate cloud condensation nuclei in and around Antarctica, J. Geophys. Res.-Atmos., 102, 12839-12854, doi:10.1029/96jd02749, 1997.

O’Dowd, C. D., Facchini, M. C., Cavalli, F., Ceburnis, D., Mircea, M., Decesari, S., Fuzzi, S., Yoon, Y. J., and Putaud, J. P.: Biogenically driven organic contribution to marine aerosol, Nature, 431, 676-680, doi:10.1038/Nature02959, 2004.

O’Dowd, C., Ceburnis, D., Vaishya, A., Jenning, S. G., and Moran, E.: Cleaner air: Brightening the pollution perspective?, AIP Conf. Proc., 1557, 579-582, doi:10.1063/1.4803337, 2013.

Ovadnevaite, J., Ceburnis, D., Martucci, G., Bialek, J., Monahan, C., Rinaldi, M., Facchini, M. C., Berresheim, H., Worsnop, D. R., and O'Dowd, C.: Primary marine organic aerosol: A dichotomy of low hygroscopicity and high CCN activity, Geophys. Res. Lett., 38, L21806, doi:10.1029/2011g1048869, $2011 \mathrm{a}$.

Ovadnevaite, J., O'Dowd, C., Dall'Osto, M., Ceburnis, D., Worsnop, D. R., and Berresheim, H.: Detecting high contributions of primary organic matter to marine aerosol: A case study, Geophys. Res. Lett., 38, L02807, doi:10.1029/2010g1046083, $2011 b$.

Ovadnevaite, J., Ceburnis, D., Canagaratna, M., Berresheim, H., Bialek, J., Martucci, G., Worsnop, D. R., and O’Dowd, C.: On the effect of wind speed on submicron sea salt mass concentrations and source fluxes, J. Geophys. Res.-Atmos., 117, D16201, doi:10.1029/2011jd017379, 2012.

Quinn, P. K. and Bates, T. S.: Regional aerosol properties: Comparisons of boundary layer measurements from ACE 1, ACE 2, aerosols99, INDOEX, ACE asia, TARFOX, and NEAQS, J. Geophys. Res.-Atmos., 110, D14202, doi:10.1029/2004jd004755, 2005.

Reid, J. S., Koppmann, R., Eck, T. F., and Eleuterio, D. P.: A review of biomass burning emissions part II: intensive physical properties of biomass burning particles, Atmos. Chem. Phys., 5, 799825, doi:10.5194/acp-5-799-2005, 2005.

Rinaldi, M., Facchini, M. C., Decesari, S., Carbone, C., Finessi, E., Mircea, M., Fuzzi, S., Ceburnis, D., Ehn, M., Kulmala, M., de Leeuw, G., and O'Dowd, C. D.: On the representativeness of coastal aerosol studies to open ocean studies: Mace Head - a case study, Atmos. Chem. Phys., 9, 9635-9646, doi:10.5194/acp-99635-2009, 2009.

Rinaldi, M., Decesari, S., Finessi, E., Giulianelli, L., Carbone, C., Fuzzi, S., O’Dowd, C. D., Ceburnis, D., and Facchini, M. C.: Primary and secondary organic marine aerosol and oceanic biological activity: recent results and new perspectives for future studies, Adv. Meteorol., 2010, 310682, doi:10.1155/2010/310682, 2010.

Rinaldi, M., Decesari, S., Carbone, C., Finessi, E., Fuzzi, S., Ceburnis, D., O’Dowd, C. D., Sciare, J., Burrows, J. P., Vrekoussis, M., Ervens, B., Tsigaridis, K., and Facchini, M. C.: Evidence of a natural marine source of oxalic acid and a possible link to glyoxal, J. Geophys. Res.-Atmos., 116, D16204, doi:10.1029/2011jd015659, 2011.

Savoie, D. L., Arimoto, R., Keene, W. C., Prospero, J. M., Duce, R. A., and Galloway, J. N.: Marine biogenic and anthropogenic contributions to non-sea-salt sulfate in the marine boundary layer over the North Atlantic Ocean, J. Geophys. Res.-Atmos., 107, 4356, doi:10.1029/2001jd000970, 2002.

Sciare, J., Favez, O., Sarda-Esteve, R., Oikonomou, K., Cachier, H., and Kazan, V.: Long-term observations of carbonaceous aerosols in the Austral Ocean atmosphere: Evidence of a biogenic ma- 
rine organic source, J. Geophys. Res.-Atmos., 114, D15302, doi:10.1029/2009jd011998, 2009.

Shank, L. M., Howell, S., Clarke, A. D., Freitag, S., Brekhovskikh, V., Kapustin, V., McNaughton, C., Campos, T., and Wood, R.: Organic matter and non-refractory aerosol over the remote Southeast Pacific: oceanic and combustion sources, Atmos. Chem. Phys., 12, 557-576, doi:10.5194/acp-12-557-2012, 2012.

Singh, H. B., Anderson, B. E., Brune, W. H., Cai, C., Cohen, R. C., Crawford, J. H., Cubison, M. J., Czech, E. P., Emmons, L., Fuelberg, H. E., Huey, G., Jacob, D. J., Jimenez, J. L., Kaduwela, A., Kondo, Y., Mao, J., Olson, J. R., Sachse, G. W., Vay, S. A., Weinheimer, A., Wennberg, P. O., Wisthaler, A., and Team, A. S.: Pollution influences on atmospheric composition and chemistry at high northern latitudes: Boreal and California forest fire emissions, Atmos. Environ., 44, 4553-4564, doi:10.1016/j.atmosenv.2010.08.026, 2010.
Slingo, A.: Sensitivity of the Earths radiation budget to changes in low clouds, Nature, 343, 49-51, doi:10.1038/343049a0, 1990.

Yoon, Y. J., Ceburnis, D., Cavalli, F., Jourdan, O., Putaud, J. P., Facchini, M. C., Decesari, S., Fuzzi, S., Sellegri, K., Jennings, S. G., and O'Dowd, C. D.: Seasonal characteristics of the physicochemical properties of North Atlantic marine atmospheric aerosols, J. Geophys. Res.-Atmos., 112, D04206, doi:10.1029/2005jd007044, 2007. 